No. 2019-15
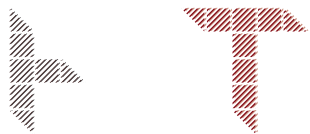

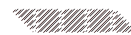

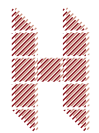

\title{
BOK
}

Working Paper
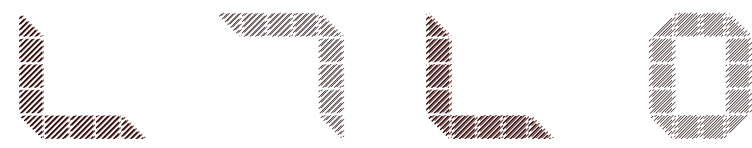

Overhead Labour and skill-Biased.

Technological change:

The Role of Product Diversification

Choong Hyum Nam

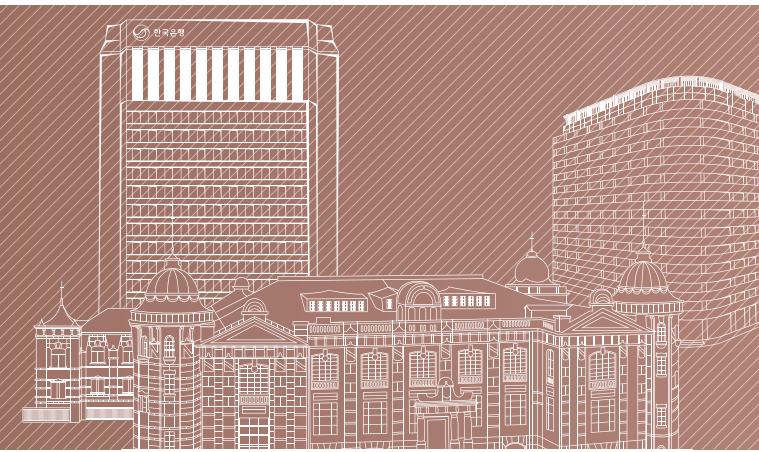

2019. 4
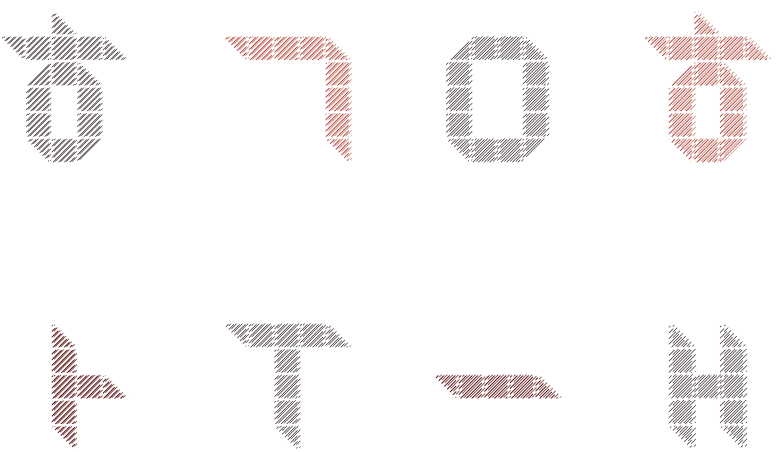

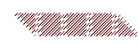
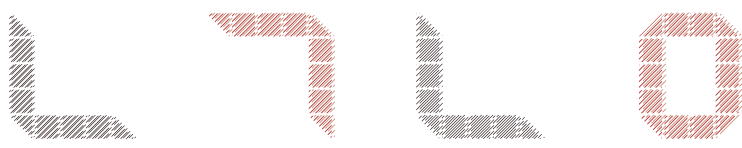
Economic Research Institute

Bank of Korea

Publisher

Juyeol Lee

(Governor of Bank of Korea)

Editor

Woon Shin

(Director General of the Institute)
Requests for copies of publications, or for addition/changes to the mailing list, should be sent to:

Economic Research Institute

Bank of Korea

39 Namdaemunno Jung-Gu

Seoul, 110-794, Korea

E-mail: eso@bok.or.kr

Fax: 82-2-759-5410

This publication available on the BOK Economic Research Institute website (http://imer.bok.or.kr)

(C) Bank of Korea, 2019

All rights reserved.

Reproduction for educational and non-commercial purposes is permitted provided that the source is acknowledged. reflect those of Bank of Korea or the Economic Research Institute.

BOK Working Paper is occasionally published by the Economic Research Institute, Bank of Korea. This is circulated in order to stimulate discussion and comments. Articles include research achievement by the staff and visiting scholars, and selected works sponsored by the Institute.

The views expressed in this paper do not necessarily 


\section{Overhead Labour and Skill-Biased Technological Change: The Role of Product Diversification}

Choong Hyun Nam*

The views expressed herein are those of the authors and do not necessarily reflect the official views of Bank of Korea. When reporting or citing this paper, the authors' names should always be explicitly stated.

* Economist, Economic Research Institute, Bank of Korea, Tel: +82-2-759-5164, E-mail: namch@bok.or.kr

I am very grateful to Professors Mike Waterson and Thijs van Rens for their helpful advice and suggestions. I am also grateful to Professors David Autor, Paul Beaudry, Sascha Becker, David Card, Jong Jae Lee, Michael McMahon, Omer Moav, Paulo Santos Monteiro, Roberto Pancrazi, Herakles Polemarchakis, John van Reenen, Fabian Waldinger, Sangmin Aum and Namjoo Kim for their helpful comments. 


\section{Contents}

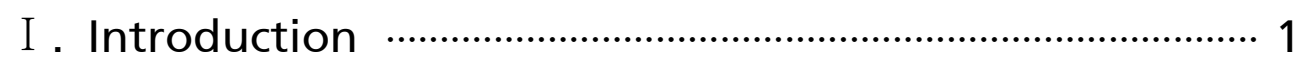

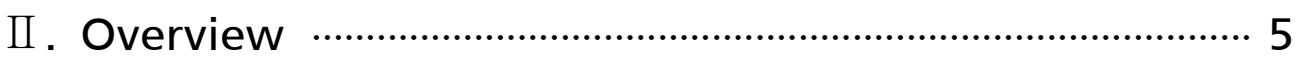

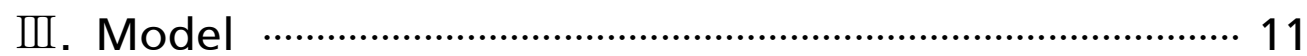

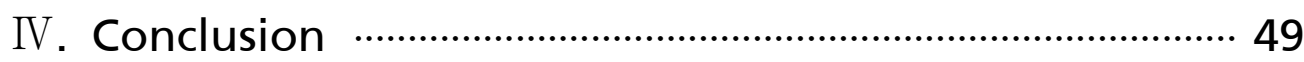

References

Appendix 


\section{Overhead Labour and Skill-Biased Technological Change: The Role of Product Diversification}

This paper tries to explain why a certain type of technology is skill-biased. In contrast with existing literature, this paper regards skilled workers as overhead labour, and presents a model wherein skilled workers constitute a fixed input, required to produce a new product. The demand for skill increases with product variety, and information technology is skill-biased because it raises product variety by lowering the fixed cost of product creation. However, skill-biased change does not necessarily raise measured productivity because product diversification reallocates resources into fixed inputs, which is consistent with the historical fact that skill-biased change did not always accompany productivity growth.

Keywords: skill demand; product innovation; inequality; productivity

JEL Classification: E24, J31, L1, O3, O4 


\section{I . Introduction}

The shift in labour demand favouring skilled workers has been found in many industrialized countries since the 1980s.1) The majority of the literature (e.g., Autor et al., 1998; Katz and Murphy, 1992; Autor et al., 2008) attributes this shift to technological change, referred to as the skill-biased technological change (SBTC) hypothesis.2) Although the literature has shown strong empirical evidence of the linkage between technology and skill-demand, the mechanism of how a certain type of technology affects skill demand remains to be contested. This paper tries to provide an alternative mechanism of skill-biased change, wherein skilled workers constitute overhead labour, in contrast with existing literature which typically assumes that both skilled and unskilled workers constitute variable labour inputs.

The most common analytical framework in the literature on skill-biased technological change, referred to by Acemoglu and Autor (2010) as the canonical model, is as follows. There are two types of labour inputs - skilled workers with university degrees and unskilled workers with a lower education level. They are imperfectly substitutable for each other, and the output good is typically assumed to be homogeneous. It is as if both skilled and unskilled workers work together in the same factory to jointly produce the same kind of good. Skill-biased change occurs if a technological change amplifies the productivity of skilled workers so that they can produce the same good more efficiently than unskilled workers. Both skilled and unskilled workers constitute variable inputs, which implies that a small increase in the employment of skilled workers increases output instantaneously.

1) The most notable example is the U.S. However, the U.K. also experienced a sharp rise in the wage gap during this period. Although this trend was noted to be less strong in countries such as Germany and Sweden (Machin and van Reenen, 1998), the increase in the relative demand for skilled workers came to be identified as common in many industrialized countries.

2) Autor et al. (1998), for example, found that the share of college-graduate workers had risen faster in more computer-intensive industries. 
In contrast, this paper assumes skilled white-collar workers are more likely to be overhead labour than blue-collar workers, and the employment of the skilled white-collar workers is not directly related with output level. Intuitively speaking, skilled workers, who are mostly non-production or white-collar workers, work in the headquarter rather than in the factory, and their task is qualitatively different from that of unskilled workers, who are mostly blue-collar or production workers. The literature suggests that non-production workers are more likely to be overhead labour or constitute quasi-fixed input (Dunne et al., 1996; Nekarda and Ramey, 2013; Gujarati and Dars, 1972; Hamermesh, 1993). ${ }^{3)}$ The fact that skilled workers are more likely to constitute overhead labour has been largely ignored in theoretical literature on skill-biased technological change. Therefore, the ensuing question is what determines the demand for the skilled overhead labour. This paper proposes that product diversification is such a determinant, although it may not be the only determinant.4)

The main assumption of the model presented in this paper is that introducing a new product requires a certain number of white-collar workers as fixed input. For example, to develop a new product, a number of white-collar workers, including engineers, designers, marketing experts, project managers and other administrative staffs, are needed irrespective of production volume. Therefore, the aggregate demand for the white-collar workers increases as product variety increases. This is consistent with the experience of the 1980s. A rapid increase in skill demand coincided with a surge in product variety as will be illustrated later in this paper.

The model features monopolistic competition with heterogeneous output goods, and product variety is endogenously determined via firm

3) In this paper, the terms "white-collar worker" and "non-production workers" are used synonymously.

4) For example, entering a foreign market may also increase the demand for overhead labour. However, entering a foreign market can be also understood as product diversification because the same type of goods sold in different countries are imperfect substitutes. 
entry and exit.5) The fixed cost includes fixed capital cost as well as fixed labour cost. For example, firms may need to buy new machine tools, which are specific to a certain type of product, to initiate the production of a new product. A fall in the fixed capital cost (of product creation) then encourages further product creation, which raises the aggregate demand for the fixed white-collar labour.6) Later in this paper, an empirical analysis is implemented and supporting evidence for the negative relationship between the fixed capital cost and the skill demand is presented.

In my model, technological change raises skill-demand mainly via lowering the fixed capital cost required to produce a new product. The diffusion of FMS (flexible manufacturing system) since the late 1970s, which include CAD (computer-aided design) and CAM (computer-aided manufacturing), is one example of such a technological change.7) As a result, product variety surged as is shown by Cox and Alm (1998) and this could have also raised the aggregate demand for the skilled fixed labour required for product creation. Such a transition from mass-production of standardized goods toward the flexible production of customized goods was possible with the adoption of computers, which explains the positive relationship between computerization and skill-demand. This paper also agrees that information technology played a significant role in skill-biased change, but this paper argues that it raises skill demand by increasing product variety, rather than by increasing the efficiency of physical production.

In contrast, the world wide diffusion of mass production of

5) In the canonical model of SBTC, due to the assumption of homogeneous final good, the contribution of product innovation to skill-biased change is largely ignored. However, product innovation is still important. According to Petrin and Warzynski (2012), in Denmark, 74 percent of total R\&D expenditure is spent on product innovation.

6) A fall in the fixed labour cost also increases product variety, but its net effect on skill-demand is uncertain because skill-demand per product declines in this case.

7) According to Milgrom and Roberts (1990), the adoption of FMS greatly reduced the capital cost of beginning production of new products. With FMS, existing equipment and assembly lines can be utilized flexibly to produce new products. 
standardized goods via assembly lines during the post-World War II period may have had the opposite effect. The adoption of the assembly line has raised production efficiency in exchange for greatly increased fixed capital cost per product, leading to the mass-production of standardized products, thereby possibly lowering the growth of the demand for fixed white-collar labour, ceteris paribus. This explains why recent developments in information technology were skill-biased, while the adoption of the assembly line was not. This statement serves as the central point of this paper, which intends to answer the question of what makes a specific technological change skill-biased.

My model generates novel predictions that help explain the puzzling discrepancies between the pace of technological change, aggregate productivity and skill-biased change. Firstly, the employment share of white-collar workers is not necessarily positively related to the measured aggregate labour productivity. It is because white-collar workers mainly constitute fixed factors, which contributes not to production quantity but to product variety. Therefore, the current measure of productivity, which understates the consumer gain from product variety, is predicted to be negatively correlated with the employment share of white-collar workers, ceteris paribus. Therefore, this paper explains the puzzling fact that periods with supposedly strong skill-biased technological change, such as the 1980s, do not always reflect higher (measured) aggregate productivity growth. However, if the current measure of productivity is ideally modified to fully capture the benefit of product variety, such measures are predicted to be positively correlated with the employment share of white-collar workers.

Secondly, skill-biased change is predicted to slow down in the long-run without any corresponding reduction in the pace of technological progress.8) A technological change that lowers fixed capital cost, such

8) However, this does not mean that income inequality will eventually stop rising. Skill-biased change is not the only driving force of income inequality, and other factors, such as rising inequality in capital income, can still raise income inequality without skill-biased change. 
as the diffusion of information technology, doesn't reduce the fixed labour cost of product creation (thereby decreasing the share of fixed capital cost in the total fixed cost). As the share of fixed capital cost in the total fixed cost declines further, any additional reduction of the total fixed cost (of product creation) becomes harder unless fixed labour cost declines as well. Although information technology might have lowered the fixed labour cost (as well as fixed capital cost), it lowers the employment of skilled fixed labour per product, leaving its net-effect on the aggregate skill-demand ambiguous. This is consistent with empirical patterns, that indicate that skill-biased change has begun to slow down recently (Autor et al., 2008; Beaudry et al., 2013) without any evidence that the progress of information technology slowed down in the 1990s, which was characterized as the decade of the New Economy.

In sum, this paper presents an alternative mechanism of skill-biased technological change, and provides novel predictions that are consistent with the observed pattern. The remainder of the paper is structured in the following way: Section II explains the canonical model of skill-biased technological change and illustrates the role of product variety in skill-biased change. Section III presents the model and its implications. Section IV concludes.

\section{Overview}

\section{The Trend in the Wage-Inequality}

The trend in the wage gap between college and non-college educated workers in the U.S. is shown in Figure 1. The wage gap increased slowly until the early 1970s, and then it began to close before increasing again dramatically in the 1980s, and continued with slower, but still positive, growth throughout the 1990s and 2000s. The dramatic shift in the 1980s drew much attention, and there was contention in a significant portion of 
the literature that the adoption of PCs in the 1980s was responsible for it.

Such a shift in the labour market was not confined to the U.S. Machin and van Reenen (1998) studied the U.S., the U.K., Germany, Japan, France, Denmark and Sweden and found that both the employment share and the wage-bill share of non-production workers rose in all of these countries, while the wage gap remained stable, with the exception of the U.S. and the U.K. The fact that the employment share rose in all the investigated countries implies that the shift in labour demand toward white-collar workers existed for all of these countries, although the wage gap did not increase for most of them.9)

Figure 1. College/High School Graduates Wage Ratio, 1963-2008

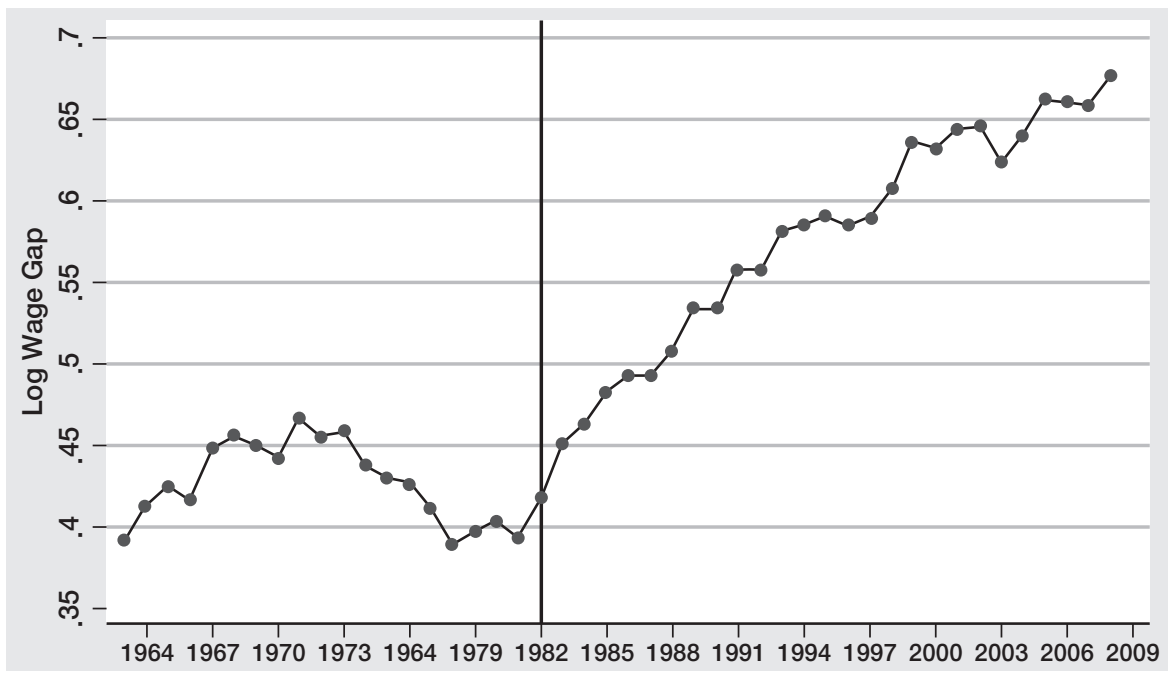

Source: Acemoglu and Autor (2010)

\section{The Canonical Model of SBTC}

In a large volume of literature on skill-biased technological change, a

9) The wage differential between non-production workers and production workers in Sweden declined slightly from 1.549 in 1977 to 1.509 in 1989, but the employment share of non-production workers rose from 0.288 to 0.303 . 
CES function with two types of labour inputs - skilled and unskilled labour - has been widely used to formulate the skill-biased technological change:10)

$$
Q_{t}=\left[\alpha_{t}\left(a_{t} N_{s, t}\right)^{\rho}+\left(1-\alpha_{t}\right)\left(b_{t} N_{u, t}\right)^{\rho}\right]^{\frac{1}{\rho}}, \quad 0<\rho<1
$$

Here, $Q_{t}$ is the output at time $t, N_{s, t}$ is the labour input of skilled workers at $t$, which is usually defined as the number of college graduate workers or white-collar workers. $N_{u, t}$ is the labour input of unskilled workers, defined as the number of workers with a lower education or blue-collar workers. Because the term "skill" only refers to educational skills, blue-collar workers with a high level of vocational training are classified as unskilled workers. Skill-biased technological change is represented either by an increase in $a_{t}$ relative to $b_{t}$ or by an absolute increase in $\alpha_{t}$. Aggregate labour productivity is the weighted average of skilled and unskilled workers' labour productivities. Therefore, skill-biased technological change is also supposed to raise aggregate productivity unless the decline in blue-collar labour augmenting technology is large enough to offset the rise in white-collar labour augmenting technology.

However, the skill-biased technological change did not come with aggregate productivity growth. Skill-biased technological change was supposed to have been the most rapid in the 1980s in the U.S. According to Card and DiNardo (2002), the puzzling fact is that the aggregate labour productivity was stagnant during the 1980s in the U.S. as is shown in Figure 2. Moreover, the aggregate labour productivity growth began to accelerate again in the 1990s, but skill-biased change slowed down for the same period (Autor et al., 2008).

One possible explanation for this puzzling result is that although a new technology raises productivity in the long-run, it requires a learning cost, which temporarily lowers aggregate labour productivity 
growth during the transitional period after a technological revolution (Galor and Moav, 2000; Hornstein and Krusell, 1996). However, this paper offers an alternative explanation that the primary motivation of technological innovation during the 1980s might have been increasing product variety rather than increasing production quantity, which leads to increased productivity mismeasurement. ${ }^{11)}$ Because the productivity slowdown was the result of the tradeoff between the quantity and the variety, its negative impact on (measured) productivity is not transitional but permanent, in contrast with existing literature.

Figure 2. Aggregate Labour Productivity

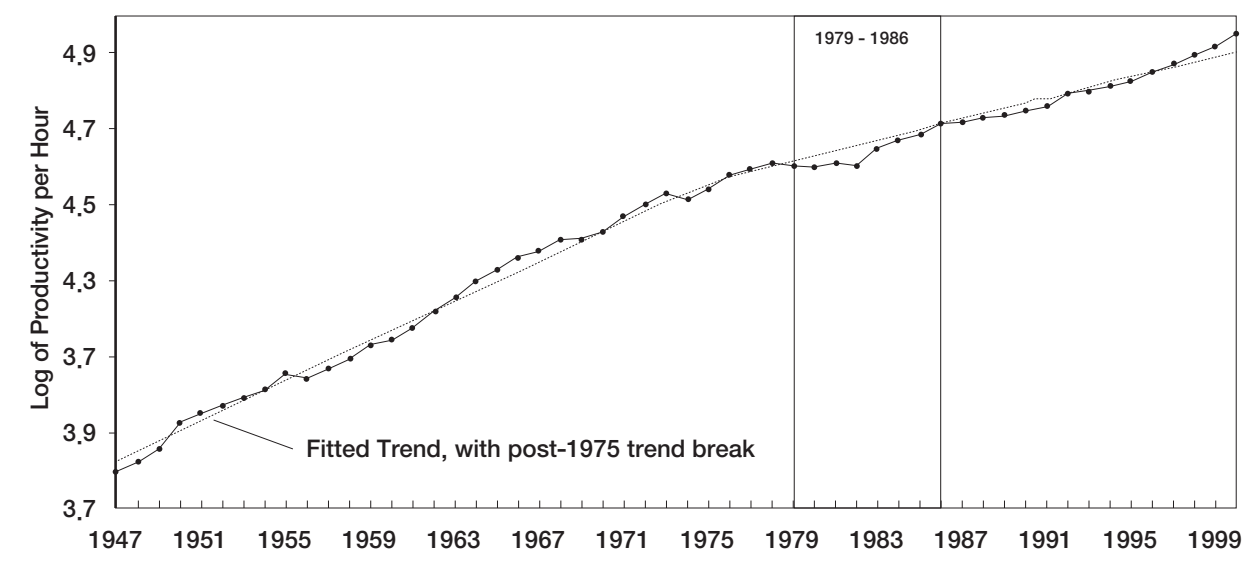

Source: Card and DiNardo (2002), Labour productivity per hour, non-farm business sector

\section{The Evolution of Product Variety}

Most of the existing literature on skill-biased technological change has largely focused on process innovation, while ignoring the role of product innovation in SBTC. However, product innovation accounts for a very

11) Horstein and Krusell (1996) also suggested that the mismeasurement of GDP and productivity could have increased after the 1970 s. 
significant part of R\&D activities. For example, according to Petrin and Warzynski (2012), $74 \%$ of the total R\&D expenditure is spent on product innovation in Denmark. Similarly, Lin and Saggi (2002) note that 'approximately three-fourths of $\mathrm{R} \& \mathrm{D}$ investments by firms in the United States are devoted to product R\&D'. However, the role of product innovation is creating new products, rather than increasing output for existing products.

Empirically measuring product variety is difficult. However, there have been some attempts, and it is known that product variety has dramatically increased since the late 1970s. According to Cox and Alm (1998), between the early 1970s and the late 1990s, the number of vehicle models available rose from 140 to 260, soft drinks from 20 to over 87, over-the-counter pain relievers from 17 to 141, running shoes from 5 to 285 and PCs from 0 to 400. Figure 3 shows how the number of vehicle models evolved over time in the U.S. since 1980.

Figure 3. The Number of Vehicle Models 1980 1997

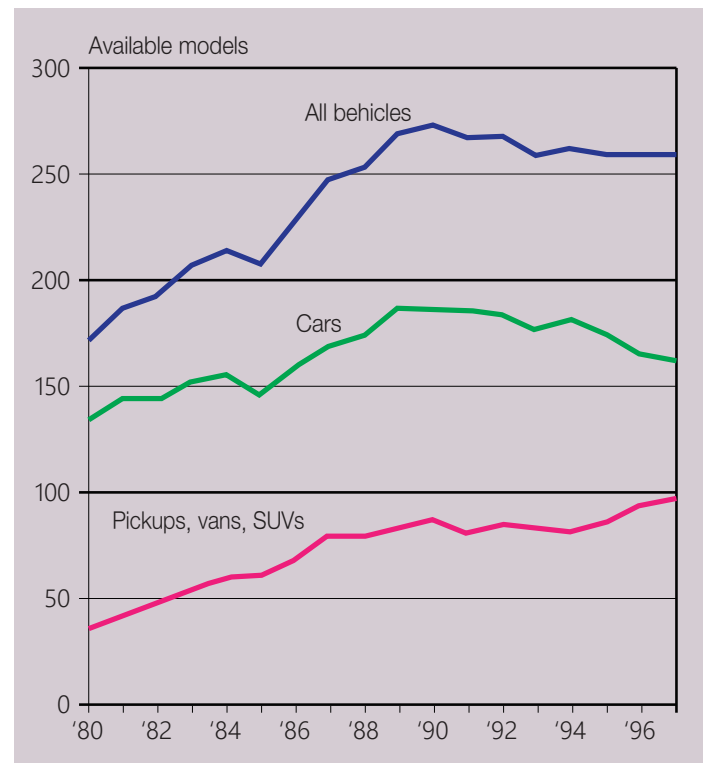

Source: "America's Move to Mass customization", Cox and Alm (1998) 
Figure 4. The Number of Firms Per Capita in the U.S.

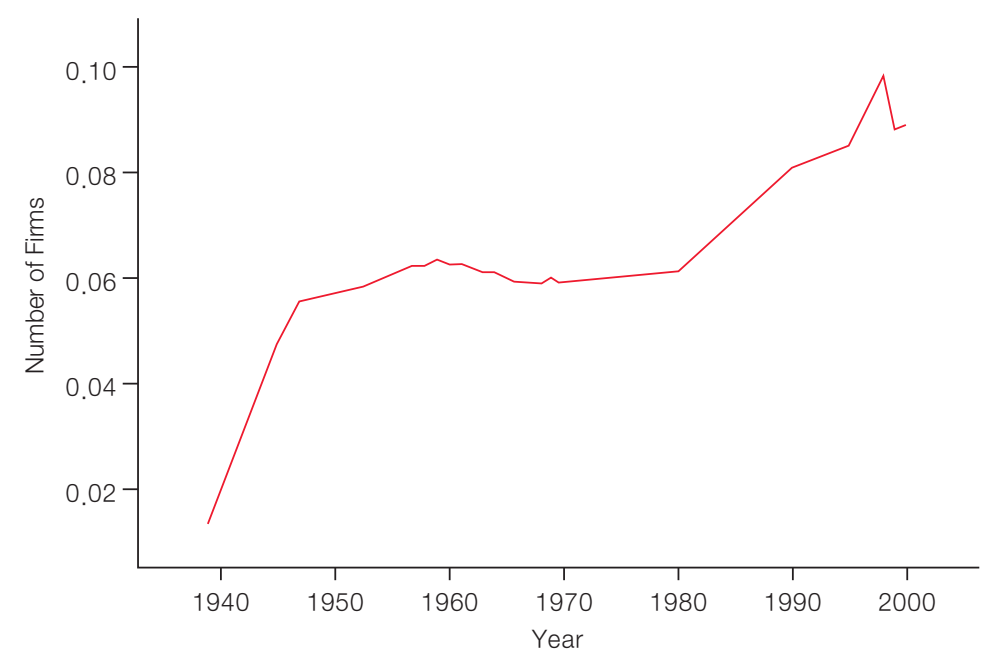

Source: Greenwood and Uysal (2005)

Greenwood and Uysal (2005) noted that the number of trademark registrations rose steadily since the 1980s, and the number of firms per capita also increased over the same period (Greenwood and Uysal, 2005) as illustrated in Figure 4. The trend of rising product variety since the 1980 s coincided with the rising wage inequality of the 1980s. ${ }^{12}$ ) The question is what mechanism lies behind that coincidence.

There exists literature investigating the role of product innovation in SBTC. Xiang (2005) has argued that the introduction of new goods favours skilled labour because new goods are produced with more skill-biased technology than existing goods. Thoenig and Verdier (2003) proposed that competitive pressure from southern low-wage countries has induced northern countries to produce skilled-labour intensive goods because they are harder for southern countries to imitate. Sanders (2002) has argued that the development of new goods is skill-biased because production of new goods requires more skilled labour, that can flexibly

12) Xiang (2005) attributes the surge in inequality in the 1980 s to the availability of new products, "such as fiber optic cables, Windows series software, VCRs and soft contact lens." 
deal with the uncertainty of production, which is higher in the early stage of product life cycle. This literature commonly assumes that introducing new products increases skill demand because the production process of new goods is more skill-intensive than old goods. ${ }^{13)}$

Nevertheless, this is not necessarily true for every new good, especially for horizontal product differentiation.14) This paper will focus on the effect of horizontal product differentiation, wherein the new goods are not necessarily technologically more sophisticated, and therefore do not necessarily require more skilled workers in the production process. This paper is also closely related with Grossmann (2002), which claims that the role of skilled labour is increasing price-cost mark-up by differentiating the good from those of competitors. While Grossmann (2002) requires the mark-up ratio to rise continuously to explain the recent skill-biased change, the model here does not need a rise in the mark-up ratio to explain such changes.

\section{Model}

In the model presented in this paper, both goods and agents (workers) are heterogeneous. Goods are imperfect substitutes and people value consumption variety as well as quantity. ${ }^{15)}$ To accommodate this 'love of variety', this paper utilises a Dixit and Stiglitz (1977) style monopolistic competition framework, wherein goods are imperfect substitutes and production of a good requires a fixed cost. While firms produce in a monopolistic competition market, individuals optimize their decisions occupation and saving - to maximize their inter-temporal utility, which is

13) This contrasts with Nelson and Phelps (1966) who argue that more educated workers are needed to adopt the latest vintage of production technology more quickly.

14) One example is the development of the white-colored iPhone 4 by Apple. It is identical to the original black version except for the color, and there are no technological improvements over the original. However, Apple spent a significant amount on R\&D on it because making the iPhone in white involved some technological difficulties, such as UV protection issues.

15) In Krugman (1979b), the motivation of technological innovation is not to produce the same goods more efficiently but to produce new goods to gain more monopoly power. 
formalized using a two period Overlapping Generation Model. The two distinctive assumptions of the model are : firstly, fixed labour input is biased toward white-collar workers (non-production workers), who are assumed to be more skilled workers ${ }^{16)}$; secondly, fixed cost includes not only the fixed labour cost but also fixed capital cost (the share of fixed capital cost in the total fixed cost falls possibly due to information technology).

\section{Consumption}

The consumption bundle of a consumer comprises of different goods, which are imperfect substitutes to each other. Following the Dixit-Stiglitz framework, a CES aggregate of the consumption bundle, $x$, is defined as:

$$
x=\left(\int_{0}^{N} q(i)^{\rho} d i\right)^{\frac{1}{\rho}}, 0<\rho<1
$$

Here, $i \in[0, N]$ is the index of the product, where $N$ is the maximum level of product variety in the economy. The consumption level of an individual good, $q(i)$, is quality-adjusted, which reflects the quality of the good as well as the quantity. ${ }^{17)}$ The constant $\rho$ represents the substitutability between different goods, and the elasticity of substitution is $\sigma=\frac{1}{1-\rho}>1$. The utility of a consumer, $u$, is an increasing function of the consumption aggregator, $x$. For simplicity, it is assumed in this paper that $u$ is a $\log$ function of $x$ :

$$
u=\ln (x)
$$

A consumer maximizes utility for a given level of monetary income,

16) In this paper, I assume that the term 'white-collar workers' is a synonym for the 'non-production workers', and that they are more skilled than production workers, while the term 'blue-collar workers' is synonymous with 'production workers'.

17) A higher value for $q(i)$ may mean either higher quantity or higher quality. 
$I$. The total expenditure for all types of goods consumed equals $I$ :

$$
\int_{0}^{N} p(i) \cdot q(i) d i=I
$$

The welfare-based consumption aggregator, $x$, is increasing in product variety, $N$, which means that consumers need a lower level of income to retain the same level of utility as $N$ grows. Therefore, the welfare-based aggregate price index, $P$, which is the price of $x$, is decreasing in $N$ :

$$
\begin{gathered}
P \cdot x=I=\int_{0}^{N} p(i) \cdot q(i) d i \\
P=\left(\int_{0}^{N} p(i)^{1-\sigma} d i\right)^{\frac{1}{1-\sigma}}
\end{gathered}
$$

Under the assumption of symmetric firms as will be shown later, the prices of individual goods, $p(i)$, are same for all goods:

$$
\begin{gathered}
p(i)=p, \text { f or all } i \in\{0, N\} \\
P=N^{\frac{1}{1-\sigma}} \cdot p
\end{gathered}
$$

It is important that the reason why the aggregate price index, $P$, is smaller than the price of individual goods, $p$, is not because of the quality upgrading of individual goods, but because of the horizontal expansion of the product range. Because $q(i)$ is assumed to be quality-adjusted, the quality of individual good is already reflected in the individual goods price, $p$. Although there have been extensive efforts to measure the quality improvement of individual goods in constructing price indices, it is unlikely that the current measure of price indices captures the welfare effect of the horizontal expansion of product range. Therefore, the degree of mismeasurement is increasing in product variety, $N .{ }^{18)}$ 


\section{Production}

Each firm $i$ produces using an identical technology following a Cobb-Douglas functional form, but production can begin only if the firm employs both fixed labour, $l_{f, i}$, and fixed capital, $k_{f, i}$, above minimum required levels $(\bar{l}, \bar{k})$ :

$$
q_{i}= \begin{cases}A \cdot l_{v, i}^{\alpha} \cdot k_{v, i}^{1-\alpha}, & \text { if } \quad l_{f, i} \geq \bar{l} \quad \& \quad k_{f, i} \geq \bar{k} \\ 0, & \text { otherwise }\end{cases}
$$

Here, $q_{i}$ is the production quantity of firm $i$, and $l_{v, i}$ and $k_{v, i}$ are variable labour and capital inputs of the firm. The parameter $A$ represents the exogenous level of skill-neutral production technology, which augments all factor inputs proportionately. 19)

\section{Product Creation}

Like typical monopolistic competition models, every firm produces a single product, and the number of products is equivalent to the number of firms. Therefore, a product is created when a firm enters into a market. However, the firm here is different from firms in the real world, because most firms are multi-product firms in reality. Therefore, the firm in the model should be understood to be a division or a production line within a firm, which is in charge of one product, rather than a firm in its entirety. Multi-product firms in the real world should be understood as a composite of multiple firms in this model.

18) In this paper, it is assumed that there is no mismeasurement arising from the failure of capturing the quality improvement of individual goods, and the only source of mismeasurement is from the failure of capturing the welfare effect of horizontal product diversification.

19) TFP growth is measured as the difference between the growth rate of output and the growth rate of total inputs which includes both fixed and variable inputs. Therefore, measured TFP growth deviates from the growth of technology, A, if the share of fixed inputs in total inputs change over time. 
A product is defined as a permanent series of products, rather than a specific type of product, whose lifespan is less than a few years at best. A product usually dies less than a few years, but is continuously replaced by a successor product. For example, when production finished of the Apple iPhone 3, it was replaced by the successor, the iPhone 4, which was a close substitute for the previous model. In this case, a product is not a specific model of iPhone, but a series of smart phones that is branded as "iPhone". A product is created within a firm when an existing product range is expanded horizontally, for example, with the introduction of the iPad or the introduction of a large screen model of the iPhone.

Even the same type of products of a firm sold in different markets (country, region, demographic group, etc.) should, in this model, be interpreted as different products produced by different firms. For example, one type of Starbucks coffee sold in the U.S. is interpreted as a different product from the same type of Starbucks coffee sold in the U.K. as long as they are imperfect substitutes. They need to hire white-collar workers at the headquarters when they expand business into another country, region or demographic group.

\section{Composition of Labour Input}

A distinctive assumption of the model is that the fixed labour input, $l_{f}$, is biased toward non-production workers (white-collar workers), who are likely to be more skilled, while the variable labour input, $l_{v}$, is biased toward production workers (blue-collar workers) who are likely to be less skilled. For example, firms need to hire a certain number of white-collar workers, such as engineers, designers, project managers and marketing staff, to develop and maintain a product (in this model, to develop a new product is equivalent to the creation of a new firm).20)

20) It is assumed that firms must keep employing the fixed labour while it is operating. It might look rather strange considering that R\&D staff is only needed for the development process. However, after a new 
However, it is hard to know the exact share of fixed labour among white-collar and blue-collar labour. Therefore, it is assumed for simplicity that the employment of blue-collar workers, $l_{b, i}$, is equivalent to the employment of variable labour, $l_{v, i}$, and the employment of white-collar workers, $l_{w, i}$, is equivalent to the employment of fixed labour, $l_{f, i}$ :

$$
\begin{aligned}
l_{v, i} & =l_{b, i} \\
l_{f, i} & =l_{w, i}
\end{aligned}
$$

This is a strong assumption because it is likely that at least some white-collar labour constitutes a variable input. However, this simplifying assumption can be justified if white-collar workers are more likely to constitute fixed labour than blue-collar workers. If so, relaxing the assumption won't qualitatively change the results. Moreover, it does not contradict the obvious fact that the employment of white-collar workers is positively related with output, either.

Although the employment of white-collar workers is assumed to be fixed for a hypothetical single-product firm in this model, it is not fixed for a multi-product firm. The product range of a firm is likely to expand as the firm grows. Firms need to access different segments of the market to increase their sales, and need to introduce a customized product to access certain market segments. According to Hottman et al. (2014), "Variation in firm quality and product scope explains at least four fifths of the variation in firm sales." Therefore, the demand for fixed white-collar labour is still positively correlated with output at a more aggregated level.

product, such as the iPhone 5, is launched, the R\&D staff are diverted to the development of the successor product, such as the iPhone 6 . 


\section{Firm's Problem}

A firm determines the levels of factor inputs and price of the final good to maximize its profit for a given set of prices:

$$
\pi_{i}=\left(p_{i}-m c_{i}\right) \cdot q_{i}-f c_{i}
$$

Here, $\pi_{i}$ is the net-profit of the firm $i, p_{i}$ is the price of its product and $q_{i}$ is the quantity of its products. $m c_{i}$ is its marginal product, which is constant, and $f c_{i}$ is its fixed costs.21) In equation (4), the first term of the RHS refers to the gross-profit of firm $i$, which is the profit before paying for fixed costs, $f c_{i}$. Due to the symmetry condition, all firms set the same price, $p$ :

$$
p^{*}=\frac{m c}{\rho}=1
$$

The price of goods, $p$, is normalized to 1 in this paper. The lower the substitutability between goods, $\rho$, the higher is the price-cost mark-up. Therefore, the mark-up is determined by the exogenous taste parameter, $p$ :

$$
\text { mark-up }=\frac{p}{m c_{i}}=\frac{1}{\rho}
$$

The total variable cost, $v c\left(q_{i}\right)$, is the sum of the variable labour cost, which equals the total wage for blue-collar workers, and variable capital cost:

$$
\begin{aligned}
v c\left(q_{i}\right) & =m c \cdot q_{i} \\
& =W_{b} \cdot l_{i}^{b}+r \cdot k_{i}^{v}
\end{aligned}
$$

21) The marginal cost is constant because the Cobb-Douglas production function exhibits constant returns to scale and the factor prices do not change with the production level of individual firms. 
Here, $W_{b}$ is the wage for blue-collar workers, and $r$ is the interest rate. The fixed cost, $f c$, which consists of fixed labour costs as well as fixed capital costs is identical for all firms:

$$
f c=W_{w} \cdot \bar{l}+r \cdot \bar{k}
$$

Here, $W_{w}$ is the wage for white-collar workers, and $\bar{l}$ is the minimum required level of fixed labour for each product, which is assumed to be identical for all firms. The employment level of white-collar workers for firm $i, l_{i}^{w}$, equals $\bar{l}$. Similarly, the employment level of fixed capital equals $\bar{k}$ for all firms. The interest rate, $r$, is the same for both variable capital and fixed capital.

The employment of blue-collar labour is determined so that the value of marginal revenue product of labour (MRPL) equals the wage. Here, $M R P L=M R \times M P L$.22) Given the above CES-preferences shown in equation (2), $M R=p \cdot \rho$. The price of the output, $p$, is normalized to 1 and $\quad M R P L=\rho \cdot \frac{\partial q_{i}}{\partial l_{b, i}}=W_{b}$. Similarly, $M R P K=\rho \cdot \frac{\partial q_{i}}{\partial k_{v, i}}=r$. Due to the symmetry condition, every firm's optimal level of employment is identical: $l_{b, i}=l_{b}$ and $k_{v, i}=k_{v}$ for all firms $i$.

\section{The Ratio Between Fixed and Variable Costs}

Products are created until the number of firms, $N$, is large enough to make a net-profit of zero. The zero-profit condition is equivalent to the condition on the equilibrium ratio between fixed and variable costs, $f v_{i}$ :

$$
f v_{i}=\frac{W_{w} \cdot \bar{l}+r \cdot \bar{k}(=f c)}{W_{b} \cdot l_{i}^{b}+r \cdot k_{i}^{v}(=v c)} ; \frac{p_{i}^{*}-m c}{m c}=\frac{1-\rho}{\rho}
$$

22) In a monopolistic competition market, $M R<P$, unlike a perfect competitive market where $M R=P$. 


$$
\begin{gathered}
f v_{i}=\frac{p_{i}^{*}-m c}{m c} \Leftrightarrow \pi_{i}=0 \\
f v_{i}>\frac{p_{i}^{*}-m c}{m c} \Leftrightarrow \pi_{i}<0 \\
f v_{i}<\frac{p_{i}^{*}-m c}{m c} \Leftrightarrow \pi_{i}>0
\end{gathered}
$$

Equation (5) shows that $f v_{i}$, the ratio between total fixed costs and total variable costs, is determined by the price-cost mark-up ratio, $\frac{p_{i}^{*}}{m c}$, which is again determined by the exogenous parameter $\rho$, representing the substitutability between products. Because the ratio between the total variable labour cost and the total variable capital cost is fixed, which equals $\frac{\alpha}{1-\alpha}$, the variable capital cost term can be substituted from the equation (5):

$$
W_{w} \cdot \bar{l}+r \cdot \bar{k}=\frac{W_{b} \cdot l_{i}^{b}}{\alpha} \cdot \frac{p_{i}^{*}-m c}{m c}
$$

Equation (6) provides an intuitive explanation for the determinants of skill-biased change, which will be further developed into a general equilibrium framework in the remainder of this paper.23) The wage bill for white-collar workers, $W_{w} \cdot \bar{l}$, increases relative to that for blue-collar workers, $W_{b} \cdot l_{i}^{b}$, for two cases. Firstly, if the mark-up ratio, $\frac{p_{i}^{*}}{m c}$, rises. Secondly, if the fixed capital cost, $r \cdot \bar{k}$, declines. These two predictions are essential for this paper, and more detailed empirical evidence supporting these are presented in the Appendix A.

23) Because the employment of white-collar workers for a firm, $\bar{l}$, is assumed to be fixed, a skill-biased change is driven by a reduction in the employment of blue-collar labour, $l_{i}^{b}$, due to a reduction in batch size. The gross-profit is proportional to the batch size, and the batch size decreases (via firm entry) until it is just enough to recover the fixed cost. 
Figure 5. Observed Wage-bill Share vs Mark-up

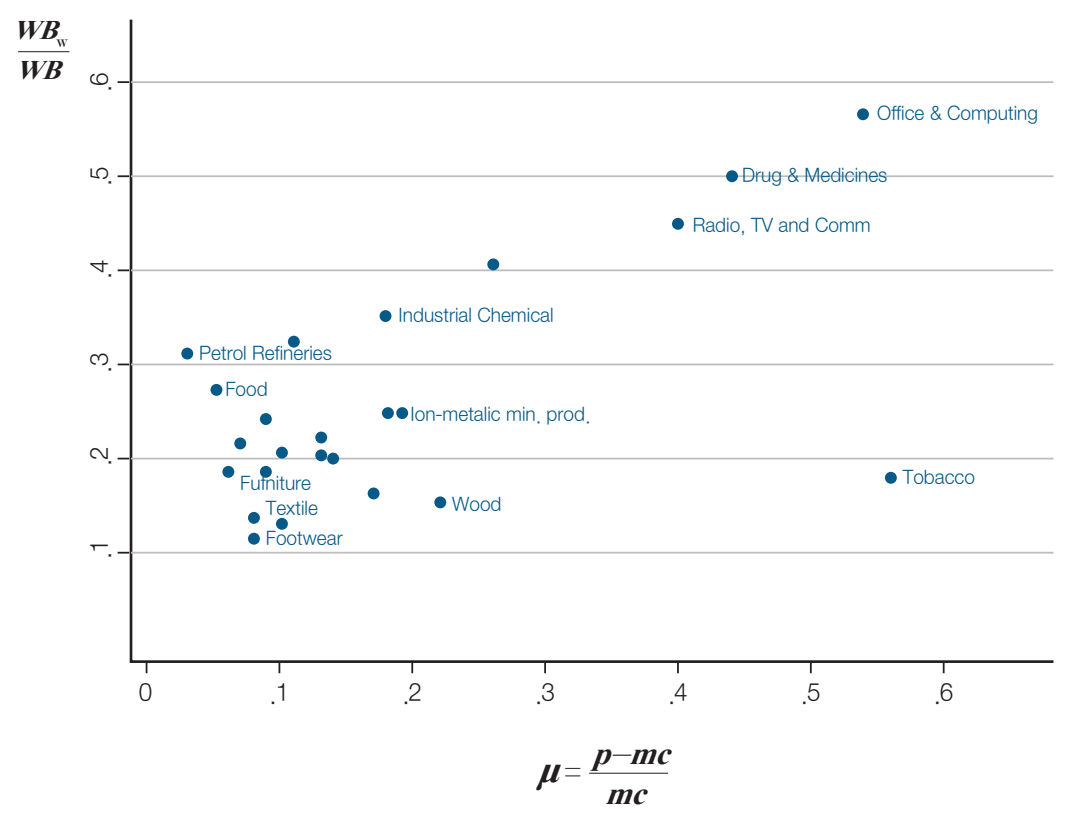

Firms with higher mark-up ratios are predicted to have a higher share of non-production workers, ceteris paribus. Those firms need smaller production quantities to recover fixed costs due to higher gross-profits per unit of output. This encourages product creation and increases demand for fixed labour (relative to variable labour). Figure 5 shows a positive correlation between the wage-bill share of non-production workers and the mark-up ratio in the U.S. manufacturing industries from the 1970 to 1992. However, a higher mark-up ratio raises skill-demand only if it comes from a higher degree of product diversification, not from a higher degree of monopoly due to entry barriers.

Firms with a lower level of fixed capital cost, ceteris paribus, also need smaller production quantity to recover fixed costs due to a lower level of total fixed cost, which leads to a higher wage-bill share of fixed labour in a zero-profit equilibrium. However, the fixed capital cost is likely to have declined over time (relative to other costs) for two reasons. Firstly, the rental rate of capital, $r$, declining relative to wages, lowers the fixed 
capital cost, $r \cdot \bar{k}$, relatively to the fixed labour cost. Secondly, some technological innovations, such as the adoption of flexible manufacturing systems(FMS), could have lowered the minimum required level of fixed capital, $\bar{k}$, as will be explained in more detail later in the paper.

Figure 6. The Share of Plant and Building in the Total Capital Stock in the U.S. Manufacturing Industries in 1970 1992

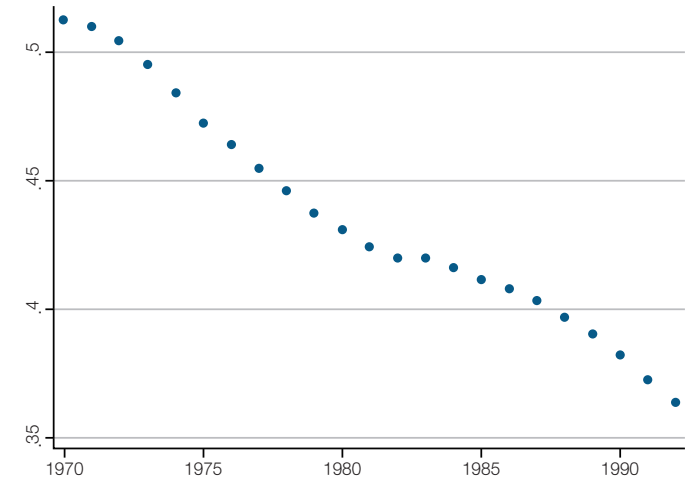

Source: NBER-CES manufacturing Industry database.

It is hard to measure the share of fixed capital in the total capital stock. However, we can utilise the presumption that capital structure is likely to be more fixed than capital equipment. In Figure 6, it is shown that the share of the capital structure has declined in the U.S. manufacturing industries between 1970 and 1992. This period coincides with the period of rising skill demand, which is consistent with the prediction.

\section{Occupational Choice and Supply of Skill}

Agents live for two periods - they work and save when they are young, and they earn interest from their savings when they are old. When they begin to work in the first period, they choose whether to take education and become a skilled worker (white-collar workers) or a 
unskilled worker (blue-collar workers). The supply of skilled white-collar labour is determined by the optimization decisions of young workers who compare the wage premium for white-collar workers and the education cost required to become a white-collar worker.

In accordance with Caselli (1999), the subjective learning cost, $\sigma_{e, i}$, is assumed to be heterogeneous across workers and only those workers whose learning cost is lower than the wage premium from education goes to university. Therefore, those with a lower learning cost will become skilled white-collar workers, while those with a higher learning cost will become unskilled blue-collar workers. Following Caselli (1999), it is assumed, for simplicity, that each individual's subjective learning cost, $\sigma_{e, i}$, follows a uniform distribution so that $\left.\sigma_{e, i} \in\left[o, \bar{\sigma}_{e}\right] .24\right) \bar{\sigma}_{e}$ is an exogenous parameter, which represents the learning cost of the worker with the highest learning cost. However, the monetary value of the subjective learning cost is defined as $\sigma_{e, i} \cdot W_{b}$. The rationale behind this is that the amount of money needed to compensate for the subjective learning cost increases as the wage level of unskilled workers rises.25) Therefore, each young worker with a subjective learning cost, $\sigma_{e, i}$, chooses to go to university and become a white-collar worker if $W_{w}-W_{b}>\sigma_{e, i} \cdot W_{b}$, which determines the aggregate labour supply of skilled white-collar workers:

$$
L_{w}^{S}=\frac{W_{w}-W_{b}}{\bar{\sigma}_{e} \cdot W_{b}} L
$$

As the wage premium increases, the threshold level of subjective learning cost, below which it is optimal to go to university, increases accordingly. Therefore, the supply of skilled white-collar labour increases

24) The subjective learning cost reflects not only tuition fees but also other opportunity costs (e.g. lost labour income, lost leisure, personal effort) and other obstacles to education, such as credit constraints.

25) The opportunity cost of education increases with wages because the foregone labour income during the period of education increases. 
as the wage premium increases, but decreases as $\bar{\sigma}_{e}$ increases.

\section{Competitive Equilibrium}

In this model, both the level of product variety and the relative demand for white-collar workers are endogenously determined given the levels of the factor endowments ( $K$ and $L$ ) and a set of exogenous parameters, which represent technology, taste and education cost.

Definition. 1. A competitive equilibrium (dynamic) is a collection of sequences for consumption and prices for each product, $\{c(i), p(i)\}_{t=0}^{\infty}$, variable and fixed factor inputs, $\left\{L_{w}, L_{b}, K_{v}, K_{f}\right\}_{t=0}^{\infty}$, the number of firms (products), $\left\{N_{t}\right\}_{t=0}^{\infty}$, wages, $\left\{W_{w}, W_{b}\right\}_{t=0}^{\infty}$, interest rate, $\{r\}_{t=0}^{\infty}$, for a set of exogenous parameters, $\rho, \bar{\sigma}_{e}, \bar{l}$ and $\bar{k}$, given the constant population, $L$ and the initial endowment of the total capital stock, $K_{0}$, which satisfy:

1. Each consumer optimally chooses consumption allocation, $c(i)_{t}$.

2. Each worker optimally chooses whether to become a white-collar worker given the wage levels, $\left(W_{w}\right.$ and $\left.W_{b}\right)$, which determines the aggregate supplies of white-collar workers as is shown in equation (7).

3. Factor allocation, $\left(L_{w}, L_{b}, K_{v}\right.$ and $\left.K_{f}\right)$, solves the firm's problem of equation (4) at each time period, t.26)

4. All goods and factor markets clear at each time period, $t$.

5. The number of firms (products), $N$, which determines both the factor allocations and the factor prices, is consistent with the zero-profit condition, at each time period, $t$.

26) Here, the factor prices $-r, W_{b}$ and $W_{w}-$ are endogenously determined and functions of $N$, while the price of good is normalized to 1 . 
The solution for the competitive equilibrium will be explained in three steps, for convenience. Firstly, a set of equilibrium solutions that satisfy market clearing conditions for a given level of the number of firms (products) and factor endowments will be derived as functions of $N, K$ and $L$. Secondly, the number of firms (products) that makes the above equilibrium solution consistent with the zero profit condition will be derived. The solution for the number of firms (products), $N$, depends on the level of the factor endowments of the period, $K_{t}$ and $L_{t}$. Thirdly, while the endowment of labour is assumed to be constant over time, the evolution of the total capital endowment, $K_{t}$, will be derived based on a two-period OLG model framework.

\subsection{Aggregation: Market Clearing Conditions}

Factor markets are cleared if the sum of the demand of individual firms for each factor input equals the supply (or endowment) of the same type of factor input in the whole economy. The demand for each type of worker must equal the supply of the same type of worker:

$$
\begin{gathered}
L_{b}^{S}=L_{b}^{D}=N \cdot l_{b} \\
L_{w}^{S}=L_{w}^{D}=N \cdot l_{w}=N \cdot \bar{l}
\end{gathered}
$$

$L_{b}$ is the total employment of blue-collar workers in the economy, and $L_{w}$ is the total employment of white-collar workers.

The total workforce, $L$, is assumed to be given exogenously but is allocated endogenously between white-collar labour and blue-collar labour. Therefore, the sum of the employment of white-collar and blue-collar labour must be set to equal to $L$.

$$
L_{b}+L_{w}=L
$$


Similarly for capital:

$$
\begin{gathered}
K_{v}=N \cdot k_{v} \\
K_{f}=N \cdot k_{f}=N \cdot \bar{k} \\
K_{v}+K_{f}=K
\end{gathered}
$$

The total capital stock in the economy, $K$, is exogenously given at each point in time, but endogenously allocated between variable part, $K_{v}$ and fixed part, $K_{f}$. However, I will show how capital stock accumulates endogenously over time later in this paper.

A set of equilibrium levels of factor prices and allocations are analytically solvable and uniquely defined given the levels of factor endowments of the economy, $L$ and $K$, and the number of firms (products) in the economy, $N$ :

$$
\begin{gathered}
L_{w}^{*}=N \cdot \bar{l} ; L_{b}^{*}=N \cdot l_{b}^{*}=L-L_{w}^{*} \\
K_{f}^{*}=N \cdot \bar{k} ; K_{v}^{*}=K-K_{f}^{*} \\
r^{*}=\rho \cdot(1-\alpha) \cdot A \cdot\left(\frac{L_{b}^{*}}{K_{v}^{*}}\right)^{\alpha} \\
W_{b}^{*}=\rho \cdot \alpha \cdot A \cdot\left(\frac{K_{v}^{*}}{L_{b}^{*}}\right)^{1-\alpha} \\
W_{w}^{*}=W_{b}^{*} \cdot\left(1+\bar{\sigma}_{e} \frac{N \cdot \bar{l}}{L}\right)
\end{gathered}
$$

The equilibrium levels of the above endogenous variables depends on $N$. Hence, the profit, which is determined by the above variables in equation (8), is uniquely determined by $N$. It will be shown shortly after that there is a unique value of $N$ that corresponds to the zero-profit equilibrium. 


\section{Aggregate GDP}

Nominal GDP, $p Y$, equals the sum of the expenditure on all types of products in the economy:

$$
p Y=\int_{0}^{N} p(i) \cdot q(i) d i=p \cdot \int_{0}^{N} q(i) d i
$$

In an equilibrium, every firm charges the same price, $p(i)=p$ and quality-adjusted production quantities are the same, $q(i)=q$, as well. Dividing the nominal GDP by $p$ yields the real GDP, $Y$, as a measure of total quantity.

$$
Y=\int_{0}^{N} q(i) d i
$$

The level of $Y$, that satisfies the market clearing condition shown above, is a function of the total variable labour and the total variable capital stock of the economy, and independent of the level of total fixed factors:

$$
Y^{*}=A \cdot\left(L_{b}^{*}\right)^{\alpha} \cdot\left(K_{v}^{*}\right)^{1-\alpha}
$$

However, the measure, $Y$, is unable to capture the benefit of horizontal product diversification and only captures the quality improvement of each individual good. Therefore, $Y$, is smaller than the CES aggregator of the goods, $x$, which is a welfare based measure of GDP, which is assumed to fully reflect the gain from product variety.

$$
x^{*}=Y^{*} \cdot N^{\frac{1-\rho}{\rho}} ; 0<\rho<1
$$

The degree of mis-measurement, which is represented by the gap between $x$ and $Y$, is increasing in product variety, $N$. 


\subsection{The Number of Products in Equilibrium}

As mentioned earlier, the zero-profit condition is equivalent to the condition that the ratio between the total fixed costs and the total variable costs, $f v$, which is an increasing function of $N$, equals the ratio between the price margin and the marginal cost, $\frac{p-m c}{m c}$ :

$$
f v(N)=\frac{W_{w}^{*}(N) \cdot \bar{l}+r^{*}(N) \cdot \bar{k}}{W_{b}^{*}(N) \cdot l_{b}^{*}(N)+r^{*}(N) \cdot k_{v}^{*}(N)}=\frac{p-m c}{m c}
$$

Here, a set of equilibrium levels of endogenous variables, $W_{w}^{*}, W_{b}^{*}$, $k_{v}^{*}, l_{b}^{*}$ and $r^{*}$, depends on $N$, while $\bar{l}, \bar{k}$ and $\rho$ are exogenous parameters, which are independent from $N$. Substituting the equilibrium levels of the endogenous variables shown in (8) into (9) leaves only one endogenous variable, $N$, with the exogenous levels of factor endowments, $K$ and $L$, and other exogenous parameters:

$$
f v(N)=N \cdot\left\{\alpha \cdot \frac{1}{L-N \cdot \bar{l}}\left(1+\bar{\sigma}_{e} \frac{N \cdot \bar{l}}{L}\right) \cdot \bar{l}+(1-\alpha) \frac{\bar{k}}{K-N \cdot \bar{k}}\right\}
$$

If $f v(N)$ is larger (smaller) than $\frac{p-m c}{m c}=\frac{1-\rho}{\rho}$, the net-profit becomes negative (positive), which results in net-exit (net-entry) of firms, reducing (increasing) the number of firms (products), $N$. The equilibrium condition for $N$ is:

$$
f v\left(N^{*}\right)=\frac{1-\rho}{\rho}\left(=\frac{p-m c}{m c}\right)
$$

By solving equation (11) for $N$, the equilibrium level of product variety, $N^{*}$, is derived. Whether there is an unique solution for $N$ is discussed in Lemma 1 as follows: 
Lemma 1. There is a unique solution for $N$, that satisfies the zero-profit condition as well as satisfies all market clearing conditions, leading to an unique solution in a competitive equilibrium.

Proof. The LHS of equation (11), $f v(N)$, is a continuous and increasing function of $N . f v(0) \rightarrow 0$, while $f v\left(\frac{L}{l}\right) \rightarrow \infty$. In contrast, the RHS of the equation is a constant representing the mark-up ratio (more precisely, the price-cost mark-up minus one). Therefore, there must be a unique solution for $N^{*}$ according to the intermediate value theorem.

Lemma 1 shows that there is an unique solution for $N^{*}$, that satisfies the zero profit condition. Then, corresponding levels of all other endogenous variables are derived accordingly, which solves for the competitive equilibrium. However, the value of $N^{*}$ depends on the factor endowments, $L$ and $K$, and other values of exogenous parameters, $\bar{l}, \bar{k}$, $\bar{\sigma}_{e}$ and $\rho$. It will be illustrated how the competitive equilibrium solution responds to the either changes in the level of factor endowments or shocks to exogenous parameters in the following sections.

Proposition 1. A decrease in the levels of exogenous parameters, $\bar{l}, \bar{k}$ and $\bar{\sigma}_{e}$, increases the equilibrium level of product variety, $N^{*}$.

Proof. Suppose the number of firms (products), $N$, is initially at the zero-profit equilibrium level, $N^{*}$. Because $\frac{\partial f v}{\partial \bar{l}}>0, \frac{\partial f v}{\partial \bar{k}}>0$, and $\frac{\partial f v}{\partial \bar{\sigma}_{e}}>0$ for any positive values of $\bar{l}, \bar{k}$ and $\bar{\sigma}_{e}$, any decreases in one of these parameters raises profit above zero. Therefore, this leads to the net entry of firms seeking a positive profit until the number of firms (products) reaches $N^{* *}>N^{*}$, where the zero-profit condition is restored. 


\subsection{The Effect of Capital Stock on Product Variety}

Following the competitive equilibrium solutions presented above, Figure 7 shows a simulation result that illustrates how the competitive equilibrium responds to a change in the total capital endowment of the economy, $K .27)$

Capital accumulation increases total output while lowering the rental rate of capital (interest rate). Therefore, the fixed capital cost per firm, $r \cdot \bar{k}$, falls as a result of capital accumulation. ${ }^{28)}$ Therefore, an increase in $K$ encourages further product creation by lowering the fixed capital cost of product creation. The demand for the fixed white-collar workers increases accordingly as product variety increases. The endowment of capital increases both product variety and the demand for the fixed white-collar labour. This is summarized as proposition 2:

Proposition 2. The effects of an increase in the level of total capital endowment, $K$, are:

(a) The equilibrium level of product variety, $N^{*}$, increases.

(b) The equilibrium levels of the employment share of white-collar workers, $\frac{L_{w}}{L}$ and their wage premium over blue-collar workers, $\frac{W_{w}}{W_{b}}$, increases.

27) The parameters assumed to derive the competitive equilibrium solutions shown in Figure 7 are: $L$ is normalized to 1 (with no population growth). The CES utility function is set so that $\rho=0.7$, which implies that the mark-up ratio equals approximately $1.43 . \bar{l}$ is 0.01 , which means that the minimum required level of fixed labour input per product is $1 \%$ of the total labour endowment of the economy. $\bar{k}=$ 0.05 , which implies that the share of the minimum required level of fixed capital input per product in the total capital endowment is $5 \%$ when $K=1$, but the share declines with capital accumulation. $\sigma_{e}=2$, which means that the upper limit of the personal education cost is twice the wage for blue-collar workers, and the wage for white-collar workers must be twice that of blue-collar workers in order to induce $50 \%$ of workers to choose university education and become white-collar workers.

28) This increases output per firm (batch size) by increasing the variable capital input per firm, but the level of fixed capital input (in real terms) per firm remains unchanged. 
Proof.

(a) Suppose the number of firms (products), $N$, is initially at zero-profit equilibrium level, $N^{*}$. In equation (10), $\frac{\partial f v}{\partial K}<0$, which means that an increase in $K$ results in a positive net-profit, leading to the net-entry of firms, thereby increasing $N$, until the number of firms (products) reaches $N^{* *}>N^{*}$, where the zero-profit condition is restored.

(b) An increase in $K$ raises the equilibrium level of product variety $N$. Equation (8) shows that both $L_{w}^{*}$ and $\frac{W_{w}^{*}}{W_{b}^{*}}$ are increasing functions of $N$.

Figure 7. Evolution of Product Variety and Skill Demand in $K$

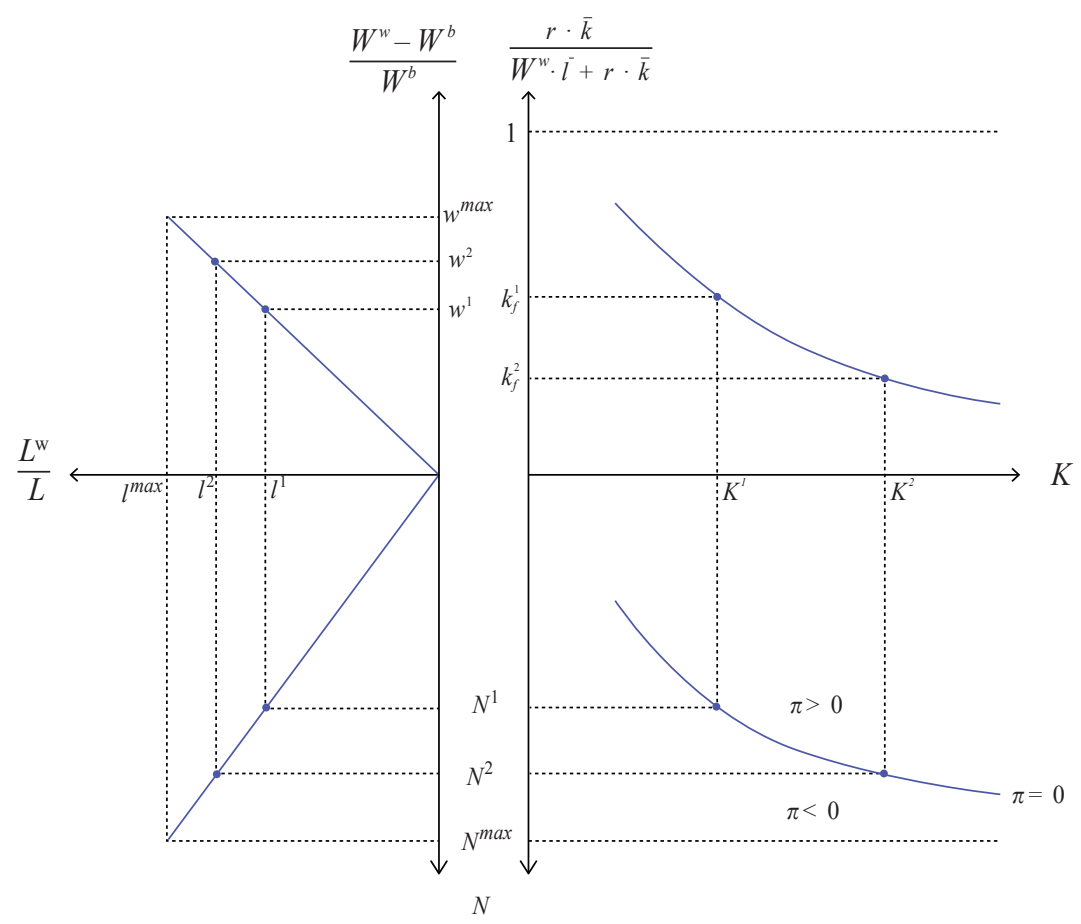


As the total capital stock, $K$, increases from $K^{1}$ to $K^{2}$, the number of products (firms), $N$, increases from $N^{1}$ to $N^{2}$, as shown in the bottom right quadrant of Figure 7. Hence, the increase in product variety increases the employment share of white-collar workers, $\frac{L^{w}}{L}$, from $l^{1}$ to $l^{2}$, as shown in the bottom left quadrant of Figure 7 . The increase in the employment share, due to an increase in product variety, increases the wage-premium, $\frac{W^{w}-W^{b}}{W^{b}}$, from $w^{1}$ to $w^{2}$, as shown in the top left quadrant of Figure 7. This is due to the fact that a higher wage premium is needed to induce more people to invest in education and become white-collar workers.

However, the growth of $N$ decelerates as $K$ grows. This is because capital accumulation lowers only the capital part of the fixed cost, whose share in the total amount of fixed costs decreases in relation to capital accumulation as shown in the top right quadrant of Figure 7. Hence, the total fixed costs of product creation decreases in relation to $K$, but at a decreasing rate. As a result, the growth of $N$, which is driven by the decrease in the fixed costs of product creation, eventually stops and converges toward a finite value, $N^{\max }$.29)

Proposition 3. As $K$ goes toward infinity, $N^{*}$ converges toward a finite value, $N^{\max }$, where $N^{\max }<\frac{L}{\bar{l}}$.

Proof. In Equation (11), the ratio between total fixed to total variable cost, $f v$, approaches infinity as $N$ approaches $\frac{L}{l}$. However, for any finite value of $N, f v$ is decreasing in $K$ and approaches toward a positive value as $K$ goes to infinity. Therefore, there always exists an equilibrium level of product variety, $N^{*}$, that satisfies the zero-profit condition for any

29) $N^{\max }$ corresponds to the equilibrium number of products (firms) if the share of fixed capital costs becomes zero. 
large value of $K$ and $N^{*}<N^{\max }<\frac{L}{\bar{l}}$.

As product variety has an upper limit, both the employment share of white-collar workers and the wage premium have upper limits as well. The corresponding upper limit of the employment share of white-collar workers is $l^{\max }$ and that of the wage premium of white-collar workers is $w^{\max }$.

Corollary 1. As $K$ goes to infinity, both the employment share of white-collar workers, $\frac{L_{w}}{L}$ and their wage premium over blue-collar workers, $\frac{W_{w}}{W_{b}}$, converge toward finite values.

Proof. As is shown in Proposition (3), $N$ converges toward a finite value, $N^{\max }$, as $K$ goes to infinity. Equation (8) shows that both $\frac{L_{w}}{L}$ and $\frac{W_{w}}{W_{b}}$ are linearly increasing functions of $N$. Therefore, both $\frac{L_{w}}{L}$ and $\frac{W_{w}}{W_{b}}$ converges toward finite values as well.

An important implication here is that skill-biased change will eventually slow if it is driven only by a declining fixed capital cost (of product creation). There are other factors that induce skill-biased change, such as an increased mark-up, but no other factors in this model are likely to have such a consistent trend as a decline in fixed capital costs. It is consistent with the empirical findings that skill-biased change has begun to slow recently (Autor et al., 2008; Beaudry et al., 2013).

The other important implication here is that an increase in the level of capital stock can increase the demand for skilled white-collar workers. Therefore, this model replicates the well known skill-complementarity hypothesis. ${ }^{30)}$ However, in contrast with the existing literature on 
skill-complementarity, which argues that capital complements skilled workers directly in the production process, capital does not either complement white-collar workers or substitute for blue-collar workers in the production process in this model.

\subsection{Capital Accumulation}

In the above sections, competitive equilibrium solutions were derived for exogenously given levels of capital stock. However, this section explains how the level of capital stock evolves endogenously. The model follows the structure of the two-period OLG model, with two distinctive points. Firstly, there are two types of agents, white-collar and blue-collar workers, who differ in their wages. Secondly, the utility of consumption in each period depends not only on the total expenditure, but also on the diversity of the consumption bundle. However, it will be shown later that the equilibrium path of capital accumulation remains largely identical to that of the standards OLG model (with homogeneous agents and goods) in spite of these differences.

In the first period, type $j$ agent earns a labour income, $W_{j, t}$. Although they differ in their wages, their preferences are identical. They divide income into consumption, $C_{j, t}$, and savings, $S_{j, t}$. In the second period, they retire and live on the capital income from the savings.

$$
\begin{gathered}
\text { young: } C_{j, t}+S_{t}=W_{j, t} \\
\text { old }: C_{j, t+1}=\left(1+r_{t+1}\right) \cdot S_{j, t} \\
j=\text { w(white-collar) or b(blue-collar) }
\end{gathered}
$$

Duffy et al. (2004) have reported a weak capital-skill complementarity, Willman et al. (2012) reject the hypothesis. Michaels et al. (2014) have found a complementarity of the skill demand with ICT capital stock but not with non-ICT capital stock. 
They maximize the inter-temporal utility by selecting the optimal level of consumption at time $t$, subject to the above budget constraint. However, each agent must choose not only how much money to spend but also choose which product to buy.

$$
\begin{gathered}
\max _{\left\{C_{t}\right\}} V\left(C_{t}\right)+\beta \cdot V\left(C_{t+1}\right) \\
V^{\prime}\left(C_{t}\right)=\beta \cdot\left(1+r_{t+1}\right) \cdot V^{\prime}\left(C_{t+1}\right)
\end{gathered}
$$

Here, $V\left(C_{t}\right)$ refers to the utility from the consumption bundle that maximizes utility for a given level of the total consumption expenditure, $C_{t}=\int_{0}^{N} p(i) \cdot c(i) d i$. Under symmetry condition, $p(i)=1$ for all $i$, and $c(i)=\frac{C_{t}}{N_{t}}$ is identical for all $i$. The maximized level of utility, $V\left(C_{t}\right)$ is:

$$
\begin{aligned}
V\left(C^{j}\right) & =\ln \left(\left\{\int_{0}^{N_{t}} c(i)^{\rho} d i\right\}^{\frac{1}{\rho}}\right) \\
& =\ln \left(N_{t}^{\left(\frac{1}{\rho}-1\right)}\right)+\ln \left(C^{j}\right)
\end{aligned}
$$

Under the assumption that the utility is the log of the composite consumption bundle, $x$, the marginal utility of consumption is not affected by product variety, $N: 31)$

$$
\therefore V^{\prime}\left(C_{t}^{j}\right)=\frac{1}{C_{t}^{j}}
$$

By applying (13) into the Euler equation of (12), the optimal consumption levels of young workers (of type $j$ ) at $t$ are:

31) The increase in product variety increases the level of utility without raising the marginal utility. 


$$
C_{t}^{j^{*}}=\frac{1}{1+\beta} \cdot W_{t}^{j}
$$

The saving rate, $\frac{S_{t}^{j}}{W_{t}^{j}}=\frac{\beta}{1+\beta}$, is the same for every agent and independent from the interest rate. One noteworthy feature is that the number of products, $N_{t}$, does not influence the optimal saving decision.

\section{The Law of the Motion of Capital}

It is assumed that the capital stock fully depreciates in one period. Therefore, the total (real) capital stock in the economy at $t+1, K_{t+1}$ equals the total (real) investment at $t, I_{t}$.

$$
K_{t+1}=I_{t}=\int_{0}^{N_{t}} I_{t}(i) d i
$$

For simplicity, it is assumed the same type of goods are used for both consumption and investment. ${ }^{32)}$ However, the total capital stock is the simple sum of each type of investment goods rather than a CES composite, which means that there is no gain by diversifying capital goods. The only gain from diversity comes from the diversity of final consumption goods in this model.

Due to deceasing marginal utility, agents will divert the same portion of every type of consumption good into investment goods. ${ }^{33)}$ The price of investment goods, $p_{I}$, is identical to the price of consumption goods, $p$, so that $p_{I}=p=1$. Therefore, $S_{t}=\int_{0}^{N_{t}} p_{I} \cdot I_{t}(i) d i=I_{t}$, and the total

32) In this model, there is no separate investment goods sector.

33) Because $c(i)$ is the same for all $i$, the ratio of investment good to consumption good, $\frac{I(i)}{c(i)}$ is the same for all $i$. 
investment, $I_{t}$, equals the total saving $S_{t} \cdot{ }^{34)}$ The total real capital stock equals the total saving of the previous period:

$$
\begin{aligned}
K_{t+1} & =S_{t} \\
& =\frac{\beta}{1+\beta} \cdot\left(W_{t}^{b} \cdot L_{b, t}+W_{t}^{w} \cdot L_{w, t}\right)
\end{aligned}
$$

$K_{t+1}$ is determined by the product of the saving rate and the sum of all agents' labour income in the previous period. In the RHS of the equation, $N_{t}, W_{t}^{w}, W_{t}^{b}, L_{t}^{w}$ and $L_{t}^{b}$ are all increasing functions of $K_{t}$. Therefore, $K_{t+1}$ can be expressed as a function of $K_{t}$, so that $K_{t+1}=g\left(K_{t}\right)$, where $g$ represents the law of motion of capital. In the steady state, $K_{t+1}=K_{t}$. In other words, $K^{*}=g\left(K^{*}\right)$ at the steady state, and $K^{*}$ is the steady state level of capital. The steady state levels of $N$, $W^{w}, W^{b}, L^{w}$ and $L^{b}$ are all determined accordingly as functions of $K^{*}$.

\section{The Effects of Exogenous Shocks}

In the model, there are three types of shocks that raises skill demand: Firstly, the shock that lowers the level of fixed capital (required for product creation). Secondly, the shock that lowers the substitutability between goods by intensifying horizontal product differentiation. Thirdly, the shock that increases skill supply by lowering education costs. Suppose the economy is initially in a steady state at $t_{1}$, while the levels of population and technology remain constant. If there is a shock, the economy reacts to the shock and begins to converge toward a new steady state. It will be discussed how the dynamic competitive equilibrium responds to such an exogenous shock in the following section.

34) Therefore, in this model there is no concern about the change in the relative price between investment goods and consumption goods. 


\subsection{The Effect of a Shock in Fixed Capital Costs}

Product creation requires a certain amount of fixed capital investment for two reasons: Firstly, there is a minimum level of capital stock required for a firm or plant to operate. Secondly, there exists a certain amount of capital equipment that is specific to the production of a certain type of product. For example, when car manufacturers wanted to expand their product range, they used to require a substantial capital investment, including adding a new assembly line to an existing plant or building a new factory.

However, the minimum required level of such fixed capital (of product creation), $\bar{k}$, is affected by technological change. For example, the adoption of the FMS (Flexible Manufacturing System) was mainly aimed at lowering the fixed capital costs of producing new products. The introduction of the microprocessor in the late 1970s not only led to the proliferation of the PC, but also encouraged the adoption of CNC (Computer Numerical Control) machines, which enabled flexible manufacturing, wherein new products could be produced on an existing assembly line with minimal changes in equipment. ${ }^{35)}$ Nowadays, it is common for a car manufacturer to produce several types of cars on the same assembly line, and it is not needed to create a new assembly line or to build a new factory to expand one's product range, which significantly lowers the fixed capital costs of product creation (by lowering $\bar{k}$ ).

Figure 8 illustrates the effects of such technology shocks, which lower $\bar{k}$. The initial steady state level of the total capital stock of the economy is $K^{*}$. After the shock occurs, the levels of total capital stock and other variables converge toward a new steady state. The shock in $\bar{k}$ affects product variety, $N$. Then, both the employment share and the relative wage of white-collar workers respond to the change in the product variety.

35) According to Mansfield (1993), 'the average year of first use of flexible manufacturing systems by major firms' is 1977. 
Figure 8. The Effects of a Shock in $\bar{k}$

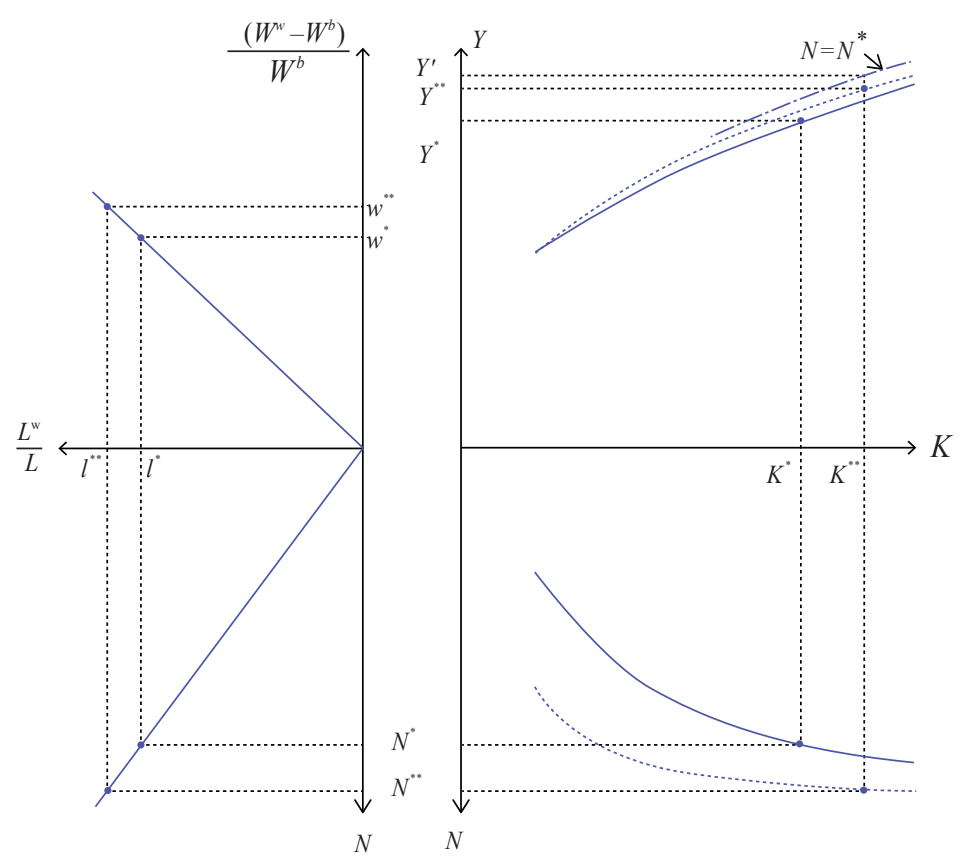

The effects of the technological shock in $\bar{k}$ are twofold: Firstly, there is a contemporaneous effect, which occurs before the level of total capital stock adjusts in response to the shock. Secondly, the shock affects capital accumulation, and the change in the level of aggregate capital stock affects skill demand.

Upon a negative shock in $\bar{k}$, the number of products (firms), $N$, increases contemporaneously, thus shifting the curve outward in the bottom right quadrant of Figure 8. Then, the increase in $N$ leads to an increase in the employment share of the white-collar workers, as shown in the bottom left quadrant. Such an increase in the employment share of white-collar workers, which is driven by a demand shift, leads to a higher wage premium for white-collar workers as is shown in the top left quadrant. The contemporaneous effects of the shock in $\bar{k}$ are summarized in Proposition 4: 
Proposition 4. For a given level of the total capital stock, $K$, the effects of a decrease in the minimum required level of fixed capital (of product creation), $\bar{k}$, are:

(a) The equilibrium level of product variety, $N^{*}$, increases for a given level of the total capital stock, $K$ (in the same period of the shock).

(b) The equilibrium levels of the employment share of white-collar workers, $\frac{L_{w}}{L}$ and their wage premium over blue-collar workers, $\frac{W_{w}}{W_{b}}$, increases (also in the same period as the shock).

\section{Proof.}

(a) Suppose the number of firms (products), $N$, is initially at zero-profit equilibrium level, $N^{*}$. Because $\frac{\partial f v}{\partial \bar{k}}>0$ for any positive values of $\bar{k}$, any decreases in the parameter raises profit above zero. Therefore, this leads to the net-entry of firms seeking positive profits until the number of firms (products) reaches $N^{* *}>N^{*}$, where the zero-profit condition is restored.

(b) A decrease in $\bar{k}$ raises the equilibrium level of product variety $N$. Equation (8) shows that both $L_{w}^{*}$ and $\frac{W_{w}^{*}}{W_{b}^{*}}$ are increasing functions of $N$.

The fall in $\bar{k}$ allows more portions of capital endowment to be variable capital, which leads to increased output. Because saving is a linearly increasing function of output, the steady state level of the aggregate capital stock increases from $K^{*}$ to $K^{* *}$. As the steady state level of the aggregate capital stock increases, the corresponding equilibrium level of product variety increases from $N^{*}$ to $N^{* *}$ and the 
employment share of white-collar workers increase from $l^{*}$ to $l^{* *}$. The wage premium increases from $w^{*}$ to $w^{* *}$ correspondingly. This indirect effect of the shock in $\bar{k}$ is summarized in Proposition 5:

Proposition 5. The effects of a fall in the level of fixed capital per product, $\bar{k}$, on the level of aggregate output, $Y$, and the steady state level of the total capital stock, $K$, are:

(a) $Y$ increases in response to the shock, but the initial increase in $Y$ is offset by the corresponding increase in $N$.

(b) As $Y$ increases, it raises the steady state level of capital stock, $K^{*}$, toward a new level, $K^{* *}$.

Proof.

(a) $Y^{*}=A \cdot(L-N \cdot \bar{l})^{\alpha} \cdot(K-N \cdot \bar{k})^{1-\alpha}$. For a given level of $N, Y$ is a decreasing function of $\bar{k}$. However, $Y$ is a decreasing function of $N$, which is a decreasing function of $\bar{k}$ as is shown in Proposition 4.

(b) An increase in $Y$ raises both the levels of consumption and investment, which equals saving, proportionally. Therefore the level of total capital stock in the next period, $K_{t+1}$, increases correspondingly. As a result, the steady state level of capital stock, $K^{*}$, changes to a new level, $K^{* *}$.

The crucial aspect of the model is that the positive effect of the fixed capital saving technological shock (which lowers $\bar{k}$ ) on the aggregate output, $Y$, is offset (at least partly) by the increase in product variety, which was induced by the same shock. If the number of firms (products) were fixed at the initial level, $N^{*}$, the aggregate output, $Y$, would rise to 
$Y^{\prime}$, which is higher than the final steady state level, $Y^{* *}$. Hence, the difference, $Y^{\prime}-Y^{* *}$, represents the lost (measured) output growth in exchange for product variety growth. Because the level of aggregate employment is assumed to be fixed at $L$, this is equivalent to the lost (measured) aggregate productivity growth. However, the shock has an unambiguously positive effect on product variety, which contributes to consumer welfare.

If it is true that the massive computerization process since the late 1970 s was aimed mainly at increasing the diversity of goods and services (rather than increasing their production quantities) by lowering the fixed capital cost of product creation, it is not surprising that its contribution to the output and productivity growth was not as impressive as the technological achievements of that era.

\subsection{Taste Shock}

In the model, the parameter $\rho$ of the CES aggregate in Equation (2), which represents the substitutability between goods, determines the price-cost mark-up. If there is a taste shock that makes goods differentiated more than before, it lowers $\rho$, and the mark-up increases. This shock can be the result of more vigorous product innovation, marketing or advertising activities. The effects of such a shock are illustrated in Figure 9.

As the shock, which lowers $\rho$, occurs, the price rises relative to the marginal cost due to increased product diversification. Therefore, the shock raises profits above zero, which leads to firm entry, and the number of firms increases until the zero-profit condition is restored. The curve in the bottom right quadrant of the figure, which represents the number of firms (products), $N_{t}$, shifts outward contemporaneously for a given level of $K$. Both the employment share and wage premium of white-collar workers increase accordingly. 
Figure 9. The Effects of a Shock in Mark-up

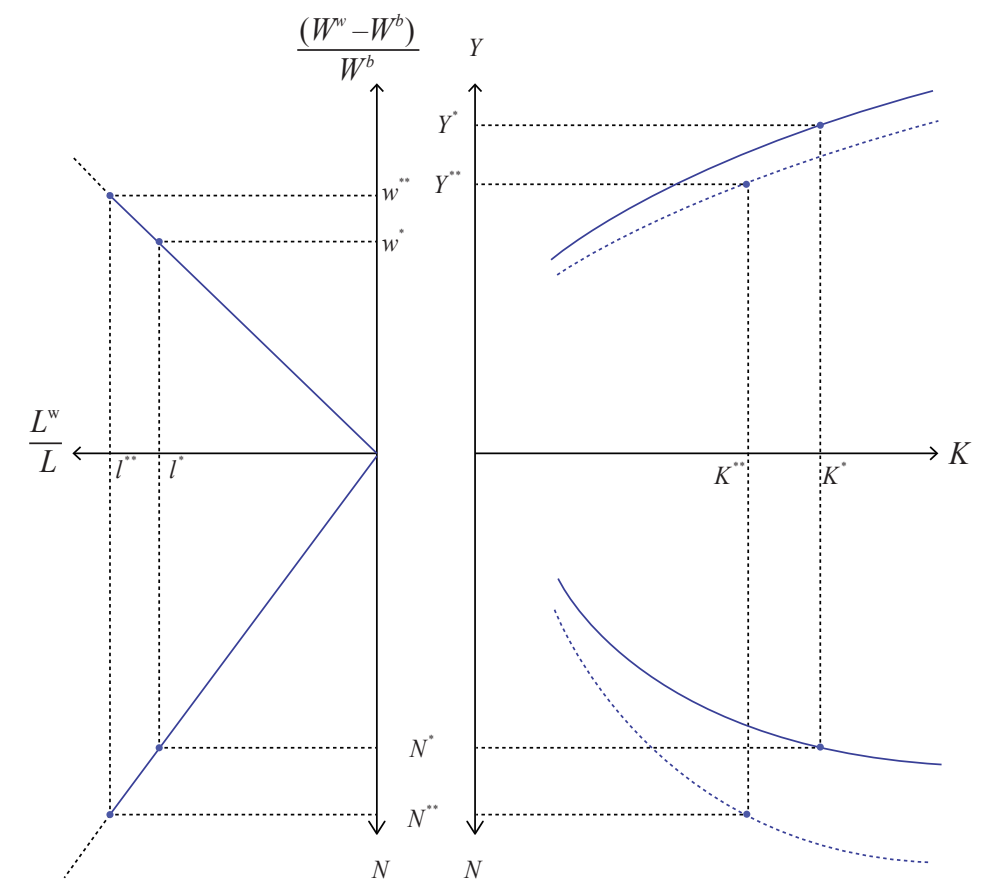

Proposition 6. For a given level of the total capital stock, $K$, the effects of a decrease in the substitutability of goods (an increase in the degree of product differentiation), $\rho$, are:

(a) The equilibrium level of product variety, $N^{*}$, increases for a given level of the total capital stock, $K$ (in the same period of the shock).

(b) The equilibrium levels of the employment share of white-collar workers, $\frac{L_{w}}{L}$ and their wage premium over blue-collar workers, $\frac{W_{w}}{W_{b}}$, increases (also in the same period as the shock). 
Proof.

(a) Suppose the number of firms (products), $N$, is initially at the zero-profit equilibrium level, $N^{*}$. As follows from equation (10) and (11), a decline in the substitutability between goods, $\rho$, raises the price of goods so that $\frac{p-m c}{m c}>f v\left(N^{*}\right)$, which raises profits above zero. Therefore, this leads to the net-entry of firms seeking a positive profit until the number of firms (products) reaches $N^{* *}>N^{*}$, where the zero-profit condition is restored.

(b) A decrease in $\rho$ raises the equilibrium level of product variety $N$. Equation (8) shows that both $L_{w}^{*}$ and $\frac{W_{w}^{*}}{W_{b}^{*}}$ are increasing functions of $N$.

However, the production quantity for each product (batch size) decreases, and variable inputs are diverted to fixed inputs to support product creation. Therefore, the aggregate output, $Y$, decreases, which leads to a decline in the level of savings and the level of total capital stock in the next period. The steady state level of capital stock decreases from $K^{*}$ to $K^{* *}$, and it negatively affects firm profits (via increased interest rate), which leads to firm exits. Therefore, the indirect effects of the shock partly offset the initial increase in product variety and skill demand by delaying capital accumulation.

Proposition 7. The effects of a decrease in the substitutability of goods, $\rho$, on the level of aggregate output, $Y$, and the steady state level of the total capital stock, $K$, are:

(a) A fall in $\rho$ lowers $Y$. 
(b) The steady state level of capital stock, $K^{*}$, decreases towards a new level, $K^{* *}$.

Proof.

(a) For a given level of $N$, a decline in $\rho$ has no effect on $Y$. However, $Y$ is a decreasing function of $N$, which is decreasing in $\rho$ as shown in Proposition 6.

(b) $\mathrm{A}$ fall in $\mathrm{Y}$ lowers both the levels of consumption and investment, which equals saving, proportionally. Therefore the level of total capital stock in the next period, $K_{t+1}$ decreases correspondingly. As a result, the steady state level of capital stock, $K^{*}$, decreases to a new level, $K^{* *}$.

\subsection{Skill Supply Shock}

In this model, the labour supply of white-collar workers is endogenously determined, and an increasing function of their wage premium over blue-collar workers as shown in Equation (7). The decline in the education cost, $\bar{\sigma}_{e}$, increases the labour supply of white-collar workers for a given level of the wage premium, shifting the labour supply curve outward. As it becomes cheaper to hire white-collar workers for product creation, firms' fixed costs decline relative to their gross-profit, which leads to firm entry and an increase in product variety. Then, the increased product variety leads to an increase in the demand for white-collar workers. The effects of the shock are illustrated in Figure 10.

Proposition 8. For a given level of the total capital stock, $K$, the effects of a fall in the education cost, which is represented by the fall in $\bar{\sigma}_{e}$, are:

(a) The equilibrium level of product variety, $N^{*}$, increases for a given 


\section{$45 \quad$ BOK Working Paper No. 2019-15}

level of the total capital stock, K(in the same period of the shock).

(b) The equilibrium levels of the employment share of white-collar workers, $\frac{L_{w}}{L}$, increases, but their wage premium over blue-collar workers, $\frac{W_{w}}{W_{b}}$, is not likely to increase.

Proof.

(a) Suppose the number of firms (products), $N$, is initially at the zero-profit equilibrium level, $N^{*}$. Because $\frac{\partial f v}{\partial \bar{\sigma}_{e}}>0$ for any positive values of $\rho$, a decline in the parameter raises profit above zero. Therefore, this leads to the net-entry of firms seeking a positive profit until the number of firms (products) reaches $N^{* *}>N^{*}$, where the zero-profit condition is restored.

(b) A decrease in $\rho$ raises the equilibrium level of product variety $N$. Equation (8) shows that both $L_{w}^{*}$ and $\frac{W_{w}^{*}}{W_{b}^{*}}$ are increasing functions of $N$. However, $W_{w}^{*}=W_{b}^{*} \cdot\left(1+\bar{\sigma}_{e} \frac{N \cdot \bar{l}}{L}\right)$ from Equation (8), and $\frac{W_{w}^{*}}{W_{b}^{*}}$ is a increasing function of $\bar{\sigma}_{e}$. Therefore, although $L_{w}^{*}$ increases unambiguously, the wage premium, $\frac{W_{w}^{*}}{W_{b}^{*}}$, does not.

After a positive skill supply shock (due to a fall in education costs), the wage premium of skilled white-collar workers over unskilled blue-collar workers declines, which is consistent with the prediction of the canonical model of skill-biased technological change.

Since the increase in the labour supply of white-collar workers encourages more diversified production, the portion of factor endowments allocated as fixed inputs (required for product creation) rises, which leads to a fall in the aggregate output, $Y$. As income declines, saving and 
investment declines and the steady stated level of total capital stock declines from $K^{*}$ to $K^{* *}$. Such a deceleration of capital accumulation partly offsets the initial increase both in product variety and skill demand.

Proposition 9. The effects of a fall in the education cost, $\bar{\sigma}_{e}$, on the level of aggregate output, $Y$, and the steady state level of the total capital stock, $K$, are:

(a) A fall in $\bar{\sigma}_{e}$ decreases $Y$ by increasing product variety, $N$, which leads to an unambiguous decline in $Y$.

(b) The steady state level of capital stock, $K^{*}$, decreases towards a new level, $K^{* *}$.

Proof.

(a) For a given level of $N, \bar{\sigma}_{e}$ has no direct effect on $Y$. However, $Y$ is a decreasing function of $N$, which is a decreasing function of $\bar{\sigma}_{e}$ as is shown in Proposition 8.

(b) A decline in $Y$ lowers both the levels of consumption and investment, which equals saving, proportionally, therefore the level of total capital stock in the next period, $K_{t+1}$ decreases correspondingly. As a result, the steady state level of capital stock, $K^{*}$, decreases to a new level, $K^{* *}$.

Nevertheless, this rather puzzling prediction of this model, that the spread of university education can actually lead to slower growth, relies on the strong assumption that the level of the skill neutral technology, $A$, which approximately represents TFP, is purely exogenous. If TFP is not exogenous and is positively affected by the employment of white-collar 
workers, an increased skill supply might contribute to production quantity as well as to product variety. Moreover, even though university education does not contribute to GDP growth, it still contributes to consumer welfare by giving more product variety to consumers. One important implication of the model is that the benefits of university education may be understated due to the limitations of current measures of GDP, which do not fully capture the welfare gain from product variety.

Figure 10. The Effects of a Shock in Education Cost

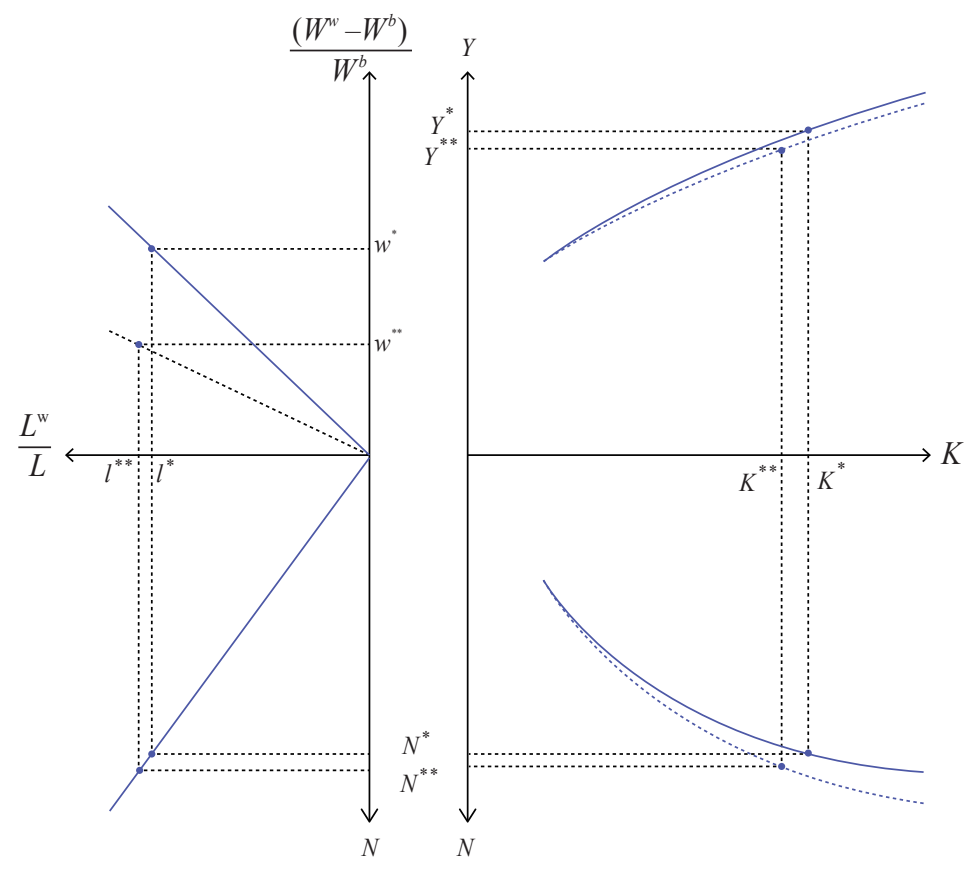

\section{Matching Empirical Patterns}

How can we explain the evolution of skill demand, wage inequality and labour productivity in recent decades? One intriguing point is that the pace of skill-biased change often deviated from that of labour productivity. Before the late 1970s, wage inequality did not show obviously upward trend although the pace of technological innovation in 
those periods were no slower than in the following decades.

We can remember the historical fact that the first landing of a human on the Moon was in 1969. Furthermore, the aggregate productivity growth rate was higher in those periods than in the following decades. A natural question is why the technological innovations of the decades preceding the 1980s did not accompany rising wage inequality, while those in the later decades did accompany it.

A dominant form of production technologies during the period was the mass production of standardized goods, which first appeared in the early 20th century. This dramatically lowered marginal cost of production while it increased the fixed costs (Cox and Alm, 1998). Hence, production efficiency improved, sacrificing product variety. It is predicted that its effects would increase the demand for variable labour (biased toward unskilled workers), relative to fixed labour (biased toward skilled workers).

Moreover, an expansion of public support for education during the period could have lowered the average education cost, raising the supply of skilled white-collar workers. The combined effects could have led to higher productivity growth and slower growth of both product variety and wage premium for skilled workers.

During the 1980s, the wage premium for skilled workers rose while the employment share for them in the total workforce increased. In the literature, it is usually attributed to the progress of information technology, such as the diffusion of computers (with micro-processors). The diffusion of computers enabled more flexible manufacturing and could have lowered the fixed capital cost of product creation. This could lead to an increase in product variety and the demand for skill, which is consistent with the observed pattern.

However, aggregate labour productivity growth in the 1980s was not as impressive as the technological achievement of the computer revolution. What this model suggests is that a large increase in product variety in 
the period could have offset the efficiency gains from computers because factor endowments were diverted from variable inputs to fixed inputs. Moreover, the diffusion of computers could have lowered the substitutability between consumer goods by creating highly differentiated goods via computerized design and targeted marketing. If so, this could have increased price-cost mark-up and further contributed to both increasing product variety and lowering (measured) productivity growth.

Nevertheless, since the 1990s, the pace of skill-biased technical change has begun to slow. It is puzzling because there was no obvious sign of a slowdown in the pace of technological innovation in the 1990s. ${ }^{36)}$ It is possible that the diffusion of PCs in the 1980s already lowered the fixed capital cost of product creation, which leaves less room for any additional decline in the fixed cost of product creation. ${ }^{37}$ ) If so, the pace of skill-biased change could decline even though the pace of technological change does not decline.

\section{Conclusion}

This paper has presented an alternative mechanism of skill-biased technological change, wherein the demand for skill comes from the fixed costs of product creation, by building a dynamic general equilibrium model with heterogeneous final goods. In the model, the relative demand for skilled workers rises when firms produce a wider range of differentiated goods, rather than when they physically increase production volume.

This model helps to answer the question of what makes a

36) For example, the world wide diffusion of the Internet was in the 1990s.

37) It probably did not lowered the fixed labour cost of product creation as much. It is due to the fact that the cognitive and flexible nature of the tasks implemented by the white-collar workers, which are required for product creation, are hard to be substituted by information technology. 
technology either skill-biased or unskill-biased. It finds that a technological change is skill-biased when it induces the diversified production of customized goods, and that it is unskill-biased when it induces the mass-production of standardized goods. However, many non-technological shocks, such as shocks in taste or education cost, also induce skill-biased changes in the model.

The model presents novel predictions. Firstly, while a positive correlation between skill-intensity (the employment share of white-collar workers) and (measured) labour productivity is predicted in the canonical model, a negative correlation can occur in this model. Secondly, it is predicted that there is an upper limit to the skill-biased change. Therefore, it is predicted that the growth of inequality between white-collar workers and blue-collar workers is likely to slow in the long run.

Several policy implications arise from this model. Firstly, rising inequality is not an inevitable by-product of technological progress. Some kinds of technological change increase inequality between skilled and unskilled workers, but there are also other kinds of technology that lowers skill demand. Secondly, rising inequality may coexist with stagnant GDP growth, which could worsen the situation of unskilled workers even further. Thirdly, public investment in education contributes to both reducing wage inequality and encouraging product innovation, but its contributions to economic welfare are likely to be underestimated due to the limitations of current GDP measures. Therefore, the contributions of education might be even bigger than we used to think. 


\section{References}

Daron Acemoglu and David Autor. Skills, Tasks and Technologies: Implications for Employment and Earnings. NBER Working Papers 16082, National Bureau of Economic Research, Inc, June 2010.

David H. Autor, Lawrence F. Katz, and Alan B. Krueger. Computing Inequality: Have Computers Changed The Labor Market? The Quarterly Journal of Economics, 113(4):1169-1213, November 1998.

David H. Autor, Lawrence F. Katz, and Melissa S. Kearney. Trends in U.S. Wage Inequality: Revising the Revisionists. The Review of Economics and Statistics, 90(2):300-323, May 2008.

Paul Beaudry, David A. Green, and Benjamin M. Sand. The Great Reversal in the Demand for Skill and Cognitive Tasks. NBER Working Papers 18901, National Bureau of Economic Research, Inc, March 2013.

David Card and John E. DiNardo. Skill-Biased Technological Change and Rising Wage Inequality: Some Problems and Puzzles. Journal of Labor Economics, 20(4):733-783, October 2002.

Francesco Caselli. Technological Revolutions. American Economic Review, 89(1):78-102, March 1999.

W. Michael Cox and Richard Alm. The right stuff: America's move to mass customization. Annual report, Federal Reserve Bank of Dallas, 1998.

Avinash K Dixit and Joseph E Stiglitz. Monopolistic Competition and Optimum Product Diversity. American Economic Review, 67(3):297-308, June 1977.

John Duffy, Chris Papageorgiou, and Fidel Perez-Sebastian. Capital-Skill Complementarity? Evidence from a Panel of Countries. The Review of Economics and Statistics, 86(1):327-344, February 2004. 
Timothy Dunne, John Haltiwanger, and Kenneth R. Troske. Technology and Jobs: Secular Changes and Cyclical Dynamics. NBER Working Papers 5656, National Bureau of Economic Research, Inc, Jul 1996.

Oded Galor and Omer Moav. Ability-Biased Technological Transition, Wage Inequality, and Economic Growth. The Quarterly Journal of Economics, 115(2):469-497, 2000.

Jeremy Greenwood and Gokce Uysal. New Goods and the Transition to a New Economy. Journal of Economic Growth, 10(2):99-134, 062005.

Volker Grossmann. Quality Improvements, the Structure of Employment, and the Skill-bias Hypothesis Revisited. The B.E. Journal of Macroeconomics, 2(1):1-25, April 2002.

Damodar N. Gujarati and Lewis Dars. Production and nonproduction workers in U.S. manufacturing industries. Industrial and Labor Relations Review, 26(1):660-669, October 1972.

Daniel S. Hamermesh. Labor Demand. Princeton University Press, 1993.

Andreas Hornstein and Per Krusell. Can Technology Improvements Cause Productivity Slowdowns? In NBER Macroeconomics Annual 1996, Volume 11, NBER Chapters, pages 209-276. National Bureau of Economic Research, Inc, June 1996.

Colin Hottman, Stephen J. Redding, and David E. Weinstein. What is 'Firm Heterogeneity' in Trade Models? The Role of Quality, Scope, Markups and Cost. CEP Discussion Papers dp1294, Centre for Economic Performance, LSE, September 2014.

Lawrence F Katz and Kevin M Murphy. Changes in Relative Wages, 1963-1987: Supply and Demand Factors. The Quarterly Journal of Economics, 107(1):35-78, February 1992.

Paul Krugman. A Model of Innovation, Technology Transfer, and the World 
Distribution of Income. Journal of Political Economy, 87(2):253-66, April 1979b.

Ping Lin and Kamal Saggi. Product differentiation, process R\&D, and the nature of market competition. European Economic Review, 46(1):201-211, January 2002.

Stephen Machin and John van Reenen. Technology And Changes In Skill Structure: Evidence From Seven Oecd Countries. The Quarterly Journal of Economics, 113(4):1215-1244, November 1998.

Edwin Mansfield. The Diffusion of Flexible Manufacturing Systems in Japan, Europe and the United States. Management Science, 39(2):149-159, February 1993.

Guy Michaels, Ashwini Natraj, and John Van Reenen. Has ICT Polarized Skill Demand? Evidence from Eleven Countries over Twenty-Five Years. The Review of Economics and Statistics, 96(1):60-77, March 2014.

Paul Milgrom and John Roberts. The Economics of Modern Manufacturing: Technology, Strategy, and Organization. American Economic Review, 80(3):511-28, June 1990.

Christopher J. Nekarda and Valerie A. Ramey. The Cyclical Behavior of the Price-Cost Markup. NBER Working Papers 19099, National Bureau of Economic Research, Inc, June 2013.

Richard R. Nelson and Edmund S. Phelps. Investment in Humans, Technological Diffusion, and Economic Growth. American Economic Review, 56(1/2):69-75, Mar 1966.

Joaquim Oliveira Martins, Stefano Scarpetta, and Dirk Pilat. Mark-Up Ratios in Manufacturing Industries: Estimates for 14 OECD Countries. OECD Economics Department Working Papers 162, OECD Publishing, 1996.

Amil Petrin and Frederic Warzynski. The Impact of Research and 
Development on Quality, Productivity and Welfare, May 2012. working paper.

Werner Roeger. Can Imperfect Competition Explain the Difference between Primal and Dual Productivity Measures? Estimates for U.S. Manufacturing. Journal of Political Economy, 103(2):316-30, April 1995.

Mark Sanders. Product lifecycles and skill-biased technical change. Research Memorandum 014, Maastricht University, Maastricht Economic Research Institute on Innovation and Technology (MERIT), 2002.

Mathias Thoenig and Thierry Verdier. A Theory of Defensive Skill-Biased Innovation and Globalization. American Economic Review, 93(3):709-728, June 2003.

Alpo Willman, Miguel Leon-Ledesma, and Peter McAdam. Explaining the Skill Premium: Technical Change or Capita-Skill Complements? EcoMod2012 4356, EcoMod, July 2012.

Chong Xiang. New Goods and the Relative Demand for Skilled Labor. The Review of Economics and Statistics, 87(2):285-298, May 2005. 


\section{Appendix A. Empirical evidences}

Most of the analysis from this paper relies on equation (5), which predicts two main relationships under the assumptions of constant marginal cost and zero net-profit equilibrium : firstly, the ratio between the total fixed and the total variable costs is determined by the price-cost mark-up,38) and secondly, the share of the fixed labour cost in the total fixed cost is negatively related with fixed capital cost. Therefore, skill-demand is predicted to be positively related with the mark-up ratio, while it is predicted to be negatively related with the fixed capital cost. This section investigates if those key predictions of the model are consistent with empirical evidence.

It has been assumed in previous sections that all firms in the economy are homogeneous. However, in this section, this assumption is relaxed for empirical analysis. The between-industry differences in the wage-bill share of white-collar workers, mark-up ratio, and the share of fixed capital are utilised for empirical analysis. Therefore, the zero-profit condition of the equation (5) is rearranged for each industry $i$ :

$$
\frac{W B_{f, i}+r \cdot K_{f, i}}{W B_{v, i}+r \cdot K_{v, i}}=\mu_{i}\left(=\frac{P_{i}-M C_{i}}{M C_{i}}\right)
$$

Here, $W B_{f, i}$ refers to the total wage bill for fixed labour in industry $i$, while $W B_{v, i}$ is for variable labour. $K_{f, i}$ refers to the fixed capital stock in the industry $i$, while $K_{v, i}$ is for variable capital. $r$ refers to rental rate of capital.

38) To be precise, it equals $\mu=$ mark-up -1 . While mark-up is the ratio between the price and the marginal cost, $\mu$ is the ratio between the gross-profit and the marginal cost. 


\section{Fixed Cost and Mark-up}

We now test whether the prediction of the equation (5) that the ratio of the total fixed to total variable cost is determined by mark-up ratio. However, we cannot directly observe how much of the total labour force is constituted by fixed or variable labour. In this paper, a strong assumption that white-collar labour is an entirely fixed input and blue-collar labour is an entirely variable input was made earlier.39) If that assumption is true, equation (14) then becomes:

$$
\frac{W B_{w}+r \cdot \widehat{s_{f}} \cdot K}{W B_{v}+r \cdot\left(1-\widehat{s_{f}}\right) \cdot K}=\widehat{\mu}
$$

Here, $W B_{w}$ is the total wage bill for white-collar workers, and $W B_{b}$ is the total wage bill for blue-collar workers. $\hat{s_{f}}$ is the share of fixed capital in the total capital stock, $k$. These values are recovered using US manufacturing data over 1970-1992, and the values of $\hat{\mu}$, which represent the ratio of fixed to variable costs, have been constructed. Because $\hat{\mu}$ is predicted to be the same as the price-cost mark-up ration, $\mu$, these two values are compared.

The data on the wage bill for both production workers and non-production workers and capital stock comes from the NBER-CES Manufacturing Industry Database, which is based on the ASM (American Survey of Manufacturers). The interest rate used here is the Baa rated corporate bond rate, which comes from the FRB (Federal Reserve Board). The inflation rate is from the U.S. Bureau of Economic Analysis.

Data on the mark-up is from Oliveira Martins et al. (1996). In that study, mark-up ratios for 36 manufacturing industries in the U.S. are estimated over 1970-1992 utilizing the method of Roeger (1995),

39) However, the term "fixed" means that it is fixed for a product (or a single-product firm), but it is not fixed at more aggregated level. 
assuming that the mark-up ratio is constant over the period.40) The list of mark-up ratios for each industry and the method of estimation are shown in the Appendix. The rental rate of capital, $r$, is derived following Oliveira Martins et al. (1996):

$$
r=((i-\pi)+\delta) \cdot p_{k}
$$

Here, $i$ is the nominal interest rate, which is equivalent to the Baa rated corporate bond rate. $\pi$ is the inflation rate, and $\delta$ is the depreciation rate, which is set to $5 \%$ per year. $p_{k}$ is the price index of the investment good.

One problem is that the share of fixed capital in the total capital stock is unobservable. To deal with that issue, the share of capital structure (plant and building) in the total capital stock is used as a proxy for the share of fixed capital. The rationale is that plants and buildings are usually adjusted more rigidly than equipment or vehicles. For example, at least one head-quarter building and one factory are needed to establish a firm. Then, it is possible to increase the stock of equipment without building another factory (upto a certain level). However, this is a rough measure because certain equipment or vehicles might be fixed capital as well.41)

$\mu$ and $\hat{\mu}$ are compared in Figure 11. A positive correlation is found between them. Industries with a higher ratio of fixed cost, such as Office \& Computing, Drug \& Medicine and Radio, TV \& Communications, are also shown to have a higher mark-up ratio. Those with a lower share of fixed cost, such as Food Products and Petrol Refineries, are shown to have a lower mark-up ratio.

40) However, not all industry groups in Oliveira Martins et al. (1996) showed significant estimates for the mark-up ratio, and only the estimates for 26 industry groups amongst them are used in this study.

41) For example, it is likely that there is a minimum level of capital equipment required to produce a product, which does not fall to zero as the production volume declines toward zero. 
Figure 11. Mark-up Ratio vs Fixed to Variable Costs Ratio

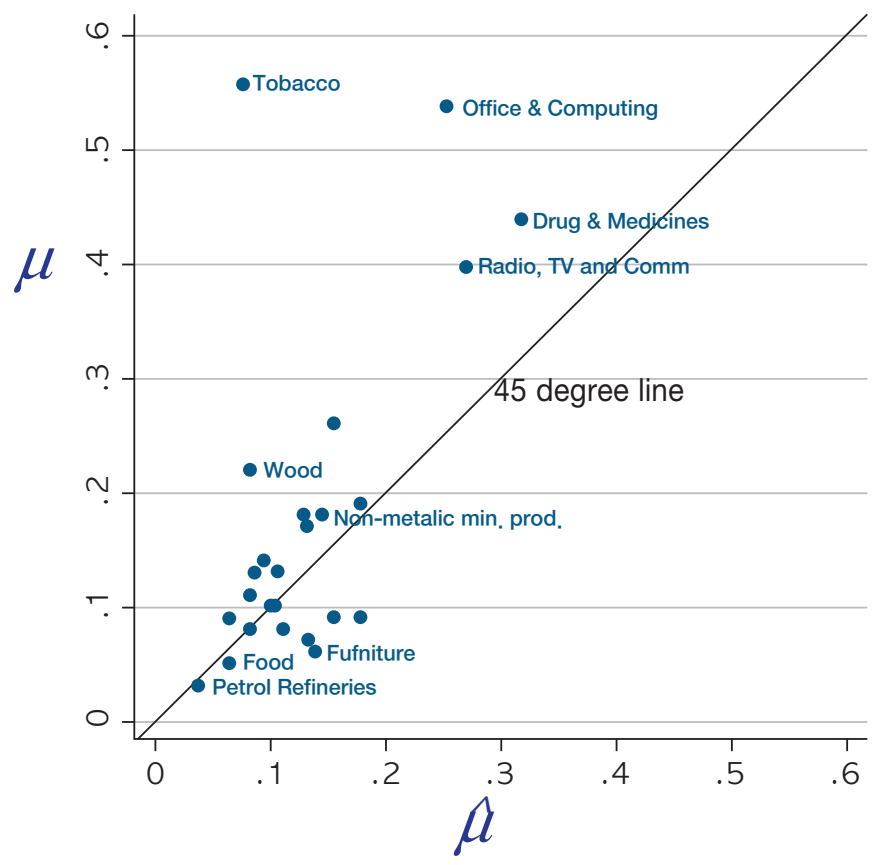

However, some industries, especially the tobacco industry, show a higher mark-up ratio, $\mu$, than the ratio of fixed to variable costs, $\hat{\mu}$. There are three possible reasons for the difference: Firstly, this difference may be due to the existence of excess profit from market power, which allows firms to charge higher prices than necessary to recover fixed costs. Secondly, although it is assumed that the share of fixed capital is equivalent to the share of capital structure (building and plant), some capital equipment may constitute fixed inputs as well, which causes a downward bias in the estimated share of fixed capital, $\hat{s_{f}}$ and the ratio of fixed to variable costs, $\hat{\mu}$. Thirdly, if the assumption of constant marginal cost is violated and the actual marginal cost is decreasing in scale, it also lowers the ratio of the total fixed to the total variable costs below the mark-up ratio. 
Figure 12. Observed wage-bill share vs predicted share

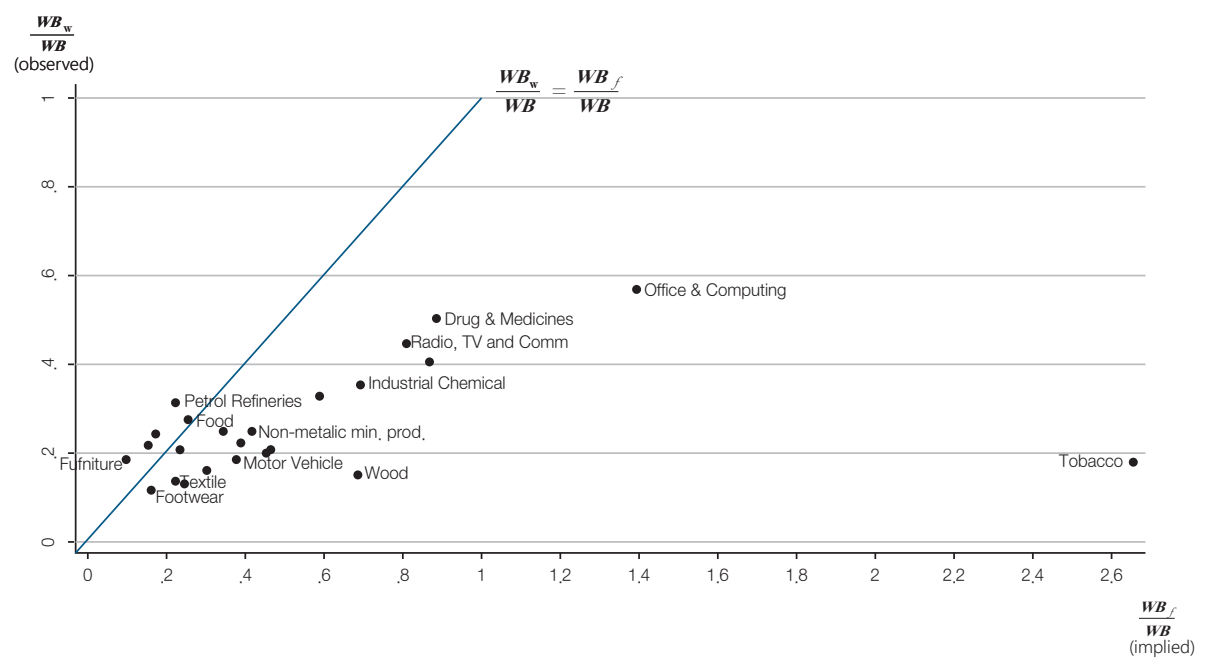

It is also possible to derive the predicted wage-bill share of white-collars (in the total wage-bill including both white-collar and blue-collar workers) from equations (14) and (15). Then, the observed wage-bill share of white-collar workers is compared with the predicted wage-bill share of the white-collar workers in Figure 12. These two are supposed to be the same if $\hat{\mu}$ is identical to $\mu$.

For the same reasons as the ratios of fixed cost to variable cost (supposed to be the same as $\mu$ ) are lower than $\mu$, the observed wage-bill shares of white-collar workers are lower than the predicted wage-bill share of the white-collar workers. The fact that the predicted wage-bill share exceeds $100 \%$ for some industries, which is impossible in reality, implies that some of the predicted wage-bill shares are overestimated. However, the observed wage-bill shares of white-collar workers are shown to be positively correlated with the predicted wage-bill shares of fixed white-collar labour. 


\section{The Ratio Between Equipment and Structure}

In the above sections, it is inferred that the share of fixed capital cost has declined over time. As this happens, the share of capital structure, which is more likely to be fixed than capital equipment, is expected to decline.

Given the ratio between fixed and variable costs, the wage-bill of white-collar workers is expected to be negatively related with fixed non-labour cost, while that of blue-collar workers is negatively related with variable non-labour cost. Therefore, the share of capital structure in the total capital stock is expected to be negatively correlated with the wage-bill share of white-collar workers (In other words, the share of equipment is positively correlated with the skill-demand).

Table 1 shows the correlations between the wage-bill share of white-collar workers, $\frac{W B^{w}}{W B}$, the mark-up ratio and the share of capital structure, $\frac{K_{s}}{K}$. The data again comes from the NBER-CES Manufacturing Industry Database, covering the period from 1970 to 1992 . Each observation corresponds to a 6-digit NAICS industry's annual average values.

It is found that the share of capital structure, $\frac{K_{s}}{K}$, is slightly positively correlated with the white-collar wage-bill share (the coefficient is 0.0562). However, $\frac{K_{s}}{K}$ is also positively correlated with the mark-up (coefficient: $0.2020)$, which is strongly positively correlated with the wage-bill share of white-collar workers, $\frac{W B^{w}}{W B}$ (coefficient: 0.4565). Therefore, the positive correlation between the share of capital structure and the wage-bill share of white-collar workers does not necessarily reflect a direct causality. 


\section{$61 \quad$ BOK Working Paper No. 2019-15}

Table 1. Correlations with the White-collar Wage-bill Share

\begin{tabular}{c|c|c|c} 
& $\frac{W B^{w}}{W B}$ & mark-up & $\frac{K_{s}}{K}$ \\
\hline \hline$\frac{W B^{w}}{W B}$ & 1 & - & - \\
\hline mark-up & 0.4565 & 1 & 1 \\
\hline$\frac{K_{s}}{K}$ & 0.0562 & 0.2020 & 1 \\
\hline
\end{tabular}

Obs: 15327

Table 2. The Effect of the Share of Capital Structure on Skill Demand: 1970 92

\begin{tabular}{c|c|c|c|c} 
& $(1)$ OLS & $(2)$ OLS & $(3) \mathrm{FE}$ & $(4) \mathrm{BE}$ \\
\hline$\frac{K_{s}}{K}$ & $0.069^{* * *}(0.013)$ & $0.008(0.013)$ & $-0.284^{* * *}(0.007)$ & $0.121^{*}(0.070)$ \\
\hline$\frac{K}{Y}$ & - & $-0.023^{* * *}(0.001)$ & $0.009^{* * *}(0.001)$ & $-0.031^{* * *}(0.007)$ \\
\hline const. & $0.324^{* * *}(0.006)$ & $0.380^{* * *}(0.007)$ & $0.476^{* * *}(0.003)$ & $0.338^{* * *}(0.036)$ \\
\hline Obs. & 10,626 & 10,626 & 10,626 & 10,626 \\
\hline
\end{tabular}

Note: 1) The dependent variable is $\frac{W B_{w}}{W B}$, the wage-bill share of white-collar workers in the industry.

2) $\frac{K_{s}}{K}$ : the ratio of capital structure to total capital stock.

$3) * * *$ : significant at $1 \%$ error level.

To distinguish the direct effect of the share of fixed capital (structure) from its indirect effect via its positive correlation with the mark-up, we should ideally include the mark-up ratios as a control variable, but the data on the mark-up ratio is not available at a more disaggregated level. Therefore, panel analysis is implemented with the assumption that the mark-up ratios are not time-varying (or at least less time-varying than other variables). The results are shown in Table 2. In the first and second column, OLS results are shown. The coefficient on the share of capital structure is shown to be positive and significant. However, the coefficient turns to insignificant once the ratio of the total capital stock to the value added output, $\frac{K}{Y}$, is included.

Moreover, the coefficient becomes negative and significant in the fixed effect result, shown in the third column of the table. In contrast, the coefficient is positive but weakly significant (at $10 \%$ error level) in the 
between effect result shown in the fourth column of the table. These contrasting results imply that the correlation between the share of capital structure, which is more likely to be fixed than capital equipment, and skill demand is negative within an industry, but positive between industries. Because the positive correlation between the unobserved level of mark-up ratio and the share of capital structure is supposed to be better controlled in the fixed effect result, the above-mentioned results are consistent with the key prediction of my model that the employment share of white-collar workers is negatively related with the share of fixed capital.

\section{Appendix B. About Mark-up Ratio Data}

The mark-up ratio data comes from Oliveira Martins et al. (1996), who utilised Roeger (1995)'s method. Roeger (1995) utilises the gap between TFPs measured by different methods. Typically, TFP is estimated by calculating Solow residual as below:

$$
S R=\Delta q-\alpha \Delta l-(1-\alpha) \Delta k
$$

Here, SR refers to the Solow residual, and $\alpha$ is the share of labour income in the output. $\triangle l, \Delta k, \triangle q$ are the differences in the logs of labour input, capital input and output. The contribution of each factor in production is equal to its income share under the assumption of perfect competition.

However, Roeger (1995) showed that TFP can also be estimated using a price-based Solow residual. It is defined by the difference between the increase in the weighted average of the factor price and the increase in the price of output as below:

$$
S R P=\alpha \Delta w-(1-\alpha) \Delta r-\Delta p
$$


Here, SPR refers to the price-based Solow residual. $\Delta w, \Delta r, \Delta p$ are the difference in the logs of wage, rental rate of capital and output price. When there is a positive technology shock, the output price rises less than the increase in the factor prices as the factors are consumed less due to the productivity improvement. In theory, under the assumption of perfect competition, TFPs estimated by both methods should be the same in theory. However, they are rarely identical in practice.

The point is that the labour's income share of output is not an accurate measure of labour's contribution to production under imperfect competition. The exact contribution of labour is equal to its income share in the marginal cost, which is lower than the price. Therefore, labour's income share of output underestimates the contribution of labour and overestimates the contribution of capital under imperfect competition. As a result, both Solow residuals are biased, but in different directions. From the gap between these two types of Solow residuals, the mark-up ratio can be estimated as below:

$$
\begin{gathered}
S R_{t}=S R P_{t}=B \triangle x_{t}+u_{t} \\
\triangle x_{t}=\left(\Delta y_{t}-\Delta k_{t}\right)+\left(\Delta p_{t}-\Delta r_{t}\right)
\end{gathered}
$$

Here, $\mathrm{B}$ is the Learner index defined as $B=\frac{P-M C}{P}$, or $B=1-\frac{1}{\mu}$, where $\mu$ is the mark-up ratio. The mark-up ratio is derived by estimating $\mathrm{B}$ in equation (21). However, Oliveira Martins et al. (1996) modify Roeger's method to incorporate material inputs in equation (21). The estimation equation used in Oliveira Martins et al. (1996) is:

$$
\triangle y_{t}=B \cdot \Delta x_{t}+\epsilon_{t}
$$

where,

$$
\begin{gathered}
\Delta y_{t}=(\Delta q+\Delta p)-\alpha \cdot(\Delta l+\Delta w)-\beta \cdot\left(\Delta m+\Delta p_{m}\right)-(1-\alpha-\beta) \cdot(\Delta k+\Delta r) \\
\Delta x_{t}=\left(\Delta y_{t}-\Delta k_{t}\right)+\left(\Delta p_{t}-\Delta r_{t}\right)
\end{gathered}
$$


Oliveira Martins et al. (1996) also adjust for the effect of indirect taxes on the estimated mark-up as below:

$$
\mu=\frac{\mu^{e}}{1+\tau}
$$

Here, $\mu^{e}$ is the estimated mark-up ratio, and $\tau$ is the indirect tax rate. Estimated mark-up ratios from Oliveira Martins et al. (1996) are shown in Table 3. The industrial classification system they use in Oliveira Martins et al. (1996) is ISIC rev.2. Data on payment, capital stock and material cost are based on NAICS 97 classification in this paper. Therefore, only ISIC rev.2 industry groups with a clear correspondence to NAICS 97 classifications are used for estimation. 
Table 3. The Mark-up Ratio in the U.S. Manufacturing, 1970 1992

\begin{tabular}{|c|c|c|c|}
\hline Sector name & (ISIC rev.2) & Sector (Naics 97) & mark-up \\
\hline Food Products & $3112 \sim$ & $311000 \sim 312000$ & 1.05 \\
\hline Beverages & $3130 \sim$ & - & - \\
\hline Tobacco products & $3140 \sim$ & $312200 \sim 313000$ & 1.56 \\
\hline Textiles & $3210 \sim$ & $313000 \sim 313000$ & 1.08 \\
\hline Wearing apparel & $3220 \sim$ & $315000 \sim 316000$ & 1.10 \\
\hline Leather products & $3230 \sim$ & $316000 \sim 321000$ & 1.08 \\
\hline Wood products & $3310 \sim$ & $321000 \sim 322000$ & 1.22 \\
\hline Furniture & 3320 & $337000 \sim 339000$ & 1.06 \\
\hline Paper products \& Pulp & $3410 \sim$ & $322000 \sim 323000$ & 1.13 \\
\hline Printing \& Publishing & $3420 \sim$ & $323000 \sim 324000$ & 1.19 \\
\hline Industrial chemicals & $3510 \sim$ & $325130 \sim 325400$ & 1.18 \\
\hline Drugs \& Medicines & 3522 & $325400 \sim 325500$ & 1.44 \\
\hline Chemical products & $3529 \sim$ & $325500 \sim 326000$ & 1.26 \\
\hline Petroleum refineries & $3530 \sim$ & 324110 & 1.03 \\
\hline Petroleum \& Coal products & 3540 & $324121 \sim 324199$ & 1.11 \\
\hline Rubber products & $3550 \sim$ & - & - \\
\hline Plastic products & 3560 & $326000 \sim 326200$ & 1.07 \\
\hline Pottery \& China & $3610 \sim$ & $327000 \sim 327200$ & 1.09 \\
\hline Glass products & $3620 \sim$ & $327200 \sim 327300$ & 1.17 \\
\hline Non-metal products & $3690 \sim$ & $327300 \sim 331000$ & 1.18 \\
\hline Iron \& Steel & $3710 \sim$ & $331000 \sim 331300$ & 1.10 \\
\hline Non-ferrous metals & $3720 \sim$ & $331300 \sim 332000$ & 1.14 \\
\hline Metal products & 3810 & $332000 \sim 333000$ & 1.09 \\
\hline Office \& Computing mach. & $3825 \sim$ & $334000 \sim 334200$ & 1.54 \\
\hline Machinery \& Equipment & $3829 \sim$ & $333000 \sim 334000$ & 1.06 \\
\hline Radio, TV \& Comm. equip. & 3832 & $334200 \sim 334300$ & 1.40 \\
\hline Electrical apparatus & 3839 & - & - \\
\hline Shipbuilding \& Repair & $3841 \sim$ & - & - \\
\hline Railroad equipment & 3842 & - & - \\
\hline Motor vehicles & 3843 & $336000 \sim 336400$ & 1.09 \\
\hline Motorcycles \& Bicycles & $3844 \sim$ & 336991 & 1.13 \\
\hline Aircraft & $3845 \sim$ & - & - \\
\hline Other transport equipment & 3849 & - & - \\
\hline Professional goods & $3850 \sim$ & - & - \\
\hline Other manufacturing & 3900 & $339000 \sim 340000$ & 1.08 \\
\hline
\end{tabular}




\section{$<$ Abstract in Korean $>$}

\section{숙련편향적 기술진보, 제품다양화 및 고정적 노동투입}

\section{남충현*}

본 연구는 기술진보가 고학력 노동수요를 증가시키는 메커니즘을 설명하고 자 하였다. 기존 연구와는 달리 본 연구에서는 고학력자의 노동을 직접적으로 생산에 투입되기 보다는 새로운 제품을 개발하기 위하여 요구되는 고정적 투입 요소로 가정한 모형을 구축하였다. 따라서, 제품 다양성의 증대는 고학력 노동에 대한 수요를 증가시키게 된다. 정보기술은 새로운 제품을 만드는데 필요한 고정 비용을 낮춰 줌으로써 제품 다양성을 증가시키며, 이러한 제품 다양성 확대는 다시 고학력 노동의 수요를 증가시키게 된다. 반면, 이러한 숙련편향적인 변화는 반드시 생산성을 높여주지 않을 수도 있는데, 이는 제품다양성의 증대를 위한 고정투입이 증가한 반면 생산량 증대를 위한 가변투입이 감소하게 되기 때문이 다. 이는 정보기술 등 숙련편향적 기술진보가 반드시 생산성의 향상을 수반하지 는 않았다는 역사적 사실과도 부합한다.

핵심 주제어: 노동수요; 제품 혁신; 불평등; 생산성

JEL Classification: E24, J31, L1, O3, O4

* 한국은행 경제연구원 미시제도연구실 부연구위원(전화: 02-759-5164, E-mail: namch@bok.or.kr) 


\section{$\mathrm{BOK}$ 경제연구 발간목록}

한국은행 경제연구원에서는 Working Paper인 『BOK 경제연구』를 수시로 발간하고 있습니다. ${ }^{\circledR} \mathrm{BOK}$ 경제연구』는 주요 경제 현상 및 정책 효과에 대한 직관적 설명 뿐 아니라 깊이 있는 이론 또는 실증 분석을 제공함으로써 엄밀한 논증에 초점을 두는 학술논문 형태의 연구이며 한국은행 직원 및 한국은행 연구용역사업의 연구 결과물이 수록되고 있습니다.

${ }^{\circledR B O K}$ 경제연구』는 한국은행 경제연구원 홈페이지(http://imer.bok.or.kr)에서 다운로드하여 보실 수 있습니다.

제2015-1글로벌 금융위기 이후 주요국 통화정책 운영체계의 변화

2 미국 장기시장금리 변동이 우리나라 금리기간구조에 미치는 영향 분석 및 정책적 시사점

3 직간접 무역연계성을 통한 해외충격의 우리나라 수출입 파급효과 분석

4 통화정책 효과의 지역적 차이

5 수입중간재의 비용효과를 고려한 환율변동과 수출가격 간의 관계

6 중앙은행의 정책금리 발표가 주식시장 유동성에 미치는 영향

7 은행 건전성지표의 변동요인과 거시건전성 규제의 영향

8 Price Discovery and Foreign Participation in The Republic of Korea's Government Bond Futures and Cash Markets

9 규제가 노동생산성에 미치는 영향: 한국의 산업패널 자료를 이용한 실증분석

10 인구 고령화와 정년연장 연구 (세대 간 중첩모형(OLG)을 이용한 정량 분석)

11 예측조합 및 밀도함수에 의한 소비자물가 상승률 전망 인플레이션 동학과 통화정책

Failure Risk and the Cross-Section of Hedge Fund Returns
Global Liquidity and Commodity Prices
김병기·김인수

강규호·오형석

최문정·김근영

김기호

김경민

이지은

강종구

Jaehun Choi • Hosung Lim • Rogelio Jr. Mercado • Cyn-Young Park

이동렬·최종일·이종한

홍재화・강태수

김현학

우준명

Jung-Min Kim

Hyunju Kang • Bok-Keun $\mathrm{Yu}$. Jongmin $\mathrm{Yu}$ 


\begin{tabular}{|c|c|c|}
\hline 제2015-15 & $\begin{array}{l}\text { Foreign Ownership, Legal System } \\
\text { and Stock Market Liquidity }\end{array}$ & $\begin{array}{l}\text { Jieun Lee } \cdot \\
\text { Kee } \mathrm{H} \text {. Chung }\end{array}$ \\
\hline 16 & $\begin{array}{l}\text { 바젤 I 은행 경기대응완충자본 규제의 } \\
\text { 기준지표에 대한 연구 }\end{array}$ & 서현덕·이정연 \\
\hline 17 & 우리나라 대출 수요와 공급의 변동요인 분석 & 강종구 · 임호성 \\
\hline 18 & 북한 인구구조의 변화 추이와 시사점 & 최지영 \\
\hline 19 & $\begin{array}{l}\text { Entry of Non-financial Firms and Competition } \\
\text { in the Retail Payments Market }\end{array}$ & Jooyong Jun \\
\hline 20 & $\begin{array}{l}\text { Monetary Policy Regime Change } \\
\text { and Regional Inflation Dynamics: } \\
\text { Looking through the Lens of } \\
\text { Sector-Level Data for Korea }\end{array}$ & $\begin{array}{l}\text { Chi-Young Choi } \\
\text { Joo Yong Lee } \\
\text { Roisin O'Sullivan }\end{array}$ \\
\hline 21 & $\begin{array}{l}\text { Costs of Foreign Capital Flows } \\
\text { in Emerging Market Economies: } \\
\text { Unexpected Economic Growth } \\
\text { and Increased Financial Market Volatility }\end{array}$ & $\begin{array}{l}\text { Kyoungsoo Yoon } \\
\text { Jayoung Kim }\end{array}$ \\
\hline 22 & $\begin{array}{l}\text { 글로벌 금리 정상화와 통화정책 과제: } \\
\text { 2015년 한국은행 국제컨퍼런스 결과보고서 }\end{array}$ & 한국은행 경제연구원 \\
\hline 23 & $\begin{array}{l}\text { The Effects of Global Liquidity } \\
\text { on Global Imbalances }\end{array}$ & $\begin{array}{l}\text { Marie-Louise DJIGBENOU-KRE } \\
\text { Hail Park }\end{array}$ \\
\hline 24 & 실물경기를 고려한 내재 유동성 측정 & 우준명·이지은 \\
\hline 25 & Deflation and Monetary Policy & Barry Eichengreen \\
\hline 26 & $\begin{array}{l}\text { Macroeconomic Shocks } \\
\text { and Dynamics of Labor Markets in Korea }\end{array}$ & $\begin{array}{l}\text { Tae Bong Kim • } \\
\text { Hangyu Lee }\end{array}$ \\
\hline 27 & $\begin{array}{l}\text { Reference Rates and Monetary Policy } \\
\text { Effectiveness in Korea }\end{array}$ & $\begin{array}{l}\text { Heung Soon Jung } \\
\text { Dong Jin Lee } \\
\text { Tae Hyo Gwon } \\
\text { Se Jin Yun }\end{array}$ \\
\hline 28 & Energy Efficiency and Firm Growth & $\begin{array}{l}\text { Bongseok Choi } \\
\text { Wooyoung Park } \\
\text { Bok-Keun Yu }\end{array}$ \\
\hline 29 & $\begin{array}{l}\text { An Analysis of Trade Patterns } \\
\text { in East Asia and the Effects of } \\
\text { the Real Exchange Rate Movements }\end{array}$ & $\begin{array}{l}\text { Moon Jung Choi } \\
\text { Geun-Young Kim. } \\
\text { Joo Yong Lee }\end{array}$ \\
\hline 30 & $\begin{array}{l}\text { Forecasting Financial Stress Indices in } \\
\text { Korea: A Factor Model Approach }\end{array}$ & $\begin{array}{l}\text { Hyeongwoo Kim } \\
\text { Hyun Hak Kim. } \\
\text { Wen Shi }\end{array}$ \\
\hline
\end{tabular}




\begin{tabular}{|c|c|c|}
\hline 제2016 -1 & $\begin{array}{l}\text { The Spillover Effects of U.S. Monetary } \\
\text { Policy on Emerging Market Economies: } \\
\text { Breaks, Asymmetries and Fundamentals }\end{array}$ & $\begin{array}{l}\text { Geun-Young Kim } \cdot \\
\text { Hail Park } \\
\text { Peter Tillmann }\end{array}$ \\
\hline 2 & $\begin{array}{l}\text { Pass-Through of Imported Input Prices to } \\
\text { Domestic Producer Prices: Evidence from } \\
\text { Sector-Level Data }\end{array}$ & $\begin{array}{l}\text { JaeBin Ahn } \\
\text { Chang-Gui Park } \\
\text { Chanho Park }\end{array}$ \\
\hline 3 & $\begin{array}{l}\text { Spillovers from U.S. Unconventional } \\
\text { Monetary Policy and Its Normalization to } \\
\text { Emerging Markets: A Capital Flow } \\
\text { Perspective }\end{array}$ & $\begin{array}{l}\text { Sangwon Suh } \\
\text { Byung-Soo Koo }\end{array}$ \\
\hline 4 & $\begin{array}{l}\text { Stock Returns and Mutual Fund Flows in } \\
\text { the Korean Financial Market: } \\
\text { A System Approach }\end{array}$ & $\begin{array}{l}\text { Jaebeom Kim } \\
\text { Jung-Min Kim }\end{array}$ \\
\hline 5 & $\begin{array}{l}\text { 정책금리 변동이 성별·세대별 고용률에 } \\
\text { 미치는 영향 }\end{array}$ & 정성엽 \\
\hline 6 & $\begin{array}{l}\text { From Firm-level Imports to } \\
\text { Aggregate Productivity: Evidence } \\
\text { from Korean Manufacturing Firms Data }\end{array}$ & $\begin{array}{l}\text { JaeBin Ahn } \\
\text { Moon Jung Choi }\end{array}$ \\
\hline 7 & $\begin{array}{l}\text { 자유무역협정(FTA)이 한국 기업의 } \\
\text { 기업내 무역에 미친 효과 }\end{array}$ & 전봉걸· 김은숙 $\cdot$ 이주용 \\
\hline 8 & $\begin{array}{l}\text { The Relation Between Monetary and } \\
\text { Macroprudential Policy }\end{array}$ & Jong Ku Kang \\
\hline 9 & $\begin{array}{l}\text { 조세피난처 투자자가 투자 기업 및 주식 } \\
\text { 시장에 미치는 영향 }\end{array}$ & 정호성·김순호 \\
\hline 10 & $\begin{array}{l}\text { 주택실거래 자료를 이용한 주택부문 거시 } \\
\text { 건전성 정책 효과 분석 }\end{array}$ & 정호성·이지은 \\
\hline 11 & $\begin{array}{l}\text { Does Intra-Regional Trade Matter in } \\
\text { Regional Stock Markets?: New Evidence } \\
\text { from Asia-Pacific Region }\end{array}$ & $\begin{array}{l}\text { Sei-Wan Kim } \\
\text { Moon Jung Choi }\end{array}$ \\
\hline 12 & $\begin{array}{l}\text { Liability, Information, and Anti-fraud } \\
\text { Investment in a Layered Retail } \\
\text { Payment Structure }\end{array}$ & $\begin{array}{l}\text { Kyoung-Soo Yoon } \\
\text { Jooyong Jun }\end{array}$ \\
\hline 13 & $\begin{array}{l}\text { Testing the Labor Market Dualism in } \\
\text { Korea }\end{array}$ & $\begin{array}{l}\text { Sungyup Chung } \\
\text { Sunyoung Jung }\end{array}$ \\
\hline 14 & $\begin{array}{l}\text { 북학 이중경제 사회계정행렬 추정을 통한 } \\
\text { 봉식부문 분석 }\end{array}$ & 최지영 \\
\hline
\end{tabular}




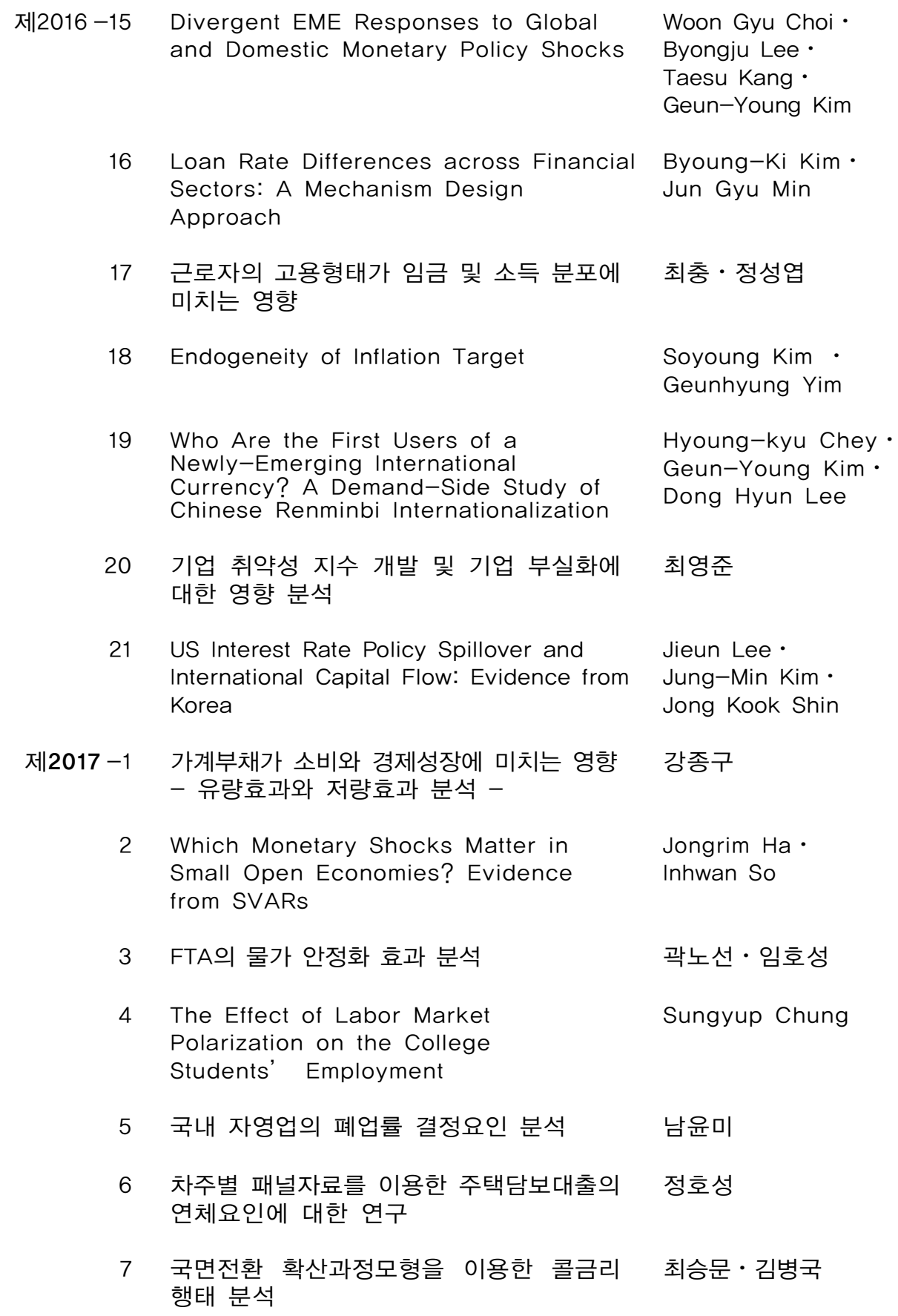

17 근로자의 고용형태가 임금 및 소득 분포에 최충 - 정성엽

20 기업 취약성 지수 개발 및 기업 부실화에 대한 영향 분석

21 US Interest Rate Policy Spillover and International Capital Flow: Evidence from Korea

Byoung-Ki Kim • Jun Gyu Min

Soyoung Kim • Geunhyung Yim

최영준

Jieun Lee $\cdot$ Jung-Min Kim• Jong Kook Shin

제2017-1 가계부채가 소비와 경제성장에 미치는 영향 강종구 - 유량효과와 저량효과 분석 -

2 Which Monetary Shocks Matter in Jongrim $\mathrm{Ha} \cdot$ Small Open Economies? Evidence Inhwan So

3 FTA의 물가 안정화 효과 분석

곽노선·임호성

4 The Effect of Labor Market Polarization on the College

Sungyup Chung Students' Employment

5 국내 자영업의 폐업률 결정요인 분석 남윤미

6 차주별 패널자료를 이용한 주택담보대출의 정호성 연체요인에 대한 연구

7 국면전환 확산과정모형을 이용한 콜금리 최승문·김병국 행태 분석 


$$
\begin{aligned}
& \text { 제2017-8 Behavioral Aspects of Household } \\
& \text { Portfolio Choice: Effects of Loss } \\
& \text { Aversion on Life Insurance Uptake } \\
& \text { and Savings } \\
& 9 \text { 신용공급 충격이 재화별 소비에 미치는 영향 김광환·최석기 } \\
& 10 \text { 유가가 손익분기인플레이션에 미치는 영향 김진용 - 김준철·임형준 } \\
& 11 \text { 인구구조변화가 인플레이션의 장기 추세에 강환구 } \\
& \text { 미치는 영향 } \\
& 12 \text { 종합적 상환여건을 반영한 과다부채 } \\
& \text { 가계의 리스크 요인 분석 } \\
& 13 \text { Crowding out in a Dual Currency Regime? } \\
& \text { Digital versus Fiat Currency } \\
& \text { KiHoon Hong } \\
& \text { Kyounghoon Park • } \\
& \text { Jongmin } \mathrm{Yu} \\
& 14 \text { Improving Forecast Accuracy of } \\
& \text { Financial Vulnerability: Partial Least } \\
& \text { Squares Factor Model Approach } \\
& 15 \text { Which Type of Trust Matters?: } \\
& \text { Interpersonal vs. Institutional vs. } \\
& \text { Political Trust } \\
& 16 \text { 기업특성에 따른 연령별 고용행태 분석 } \\
& \text { 이상욱·권철우·남윤미 } \\
& 17 \text { Equity Market Globalization and Kyungkeun Kim • } \\
& \text { Portfolio Rebalancing Dongwon Lee }
\end{aligned}
$$




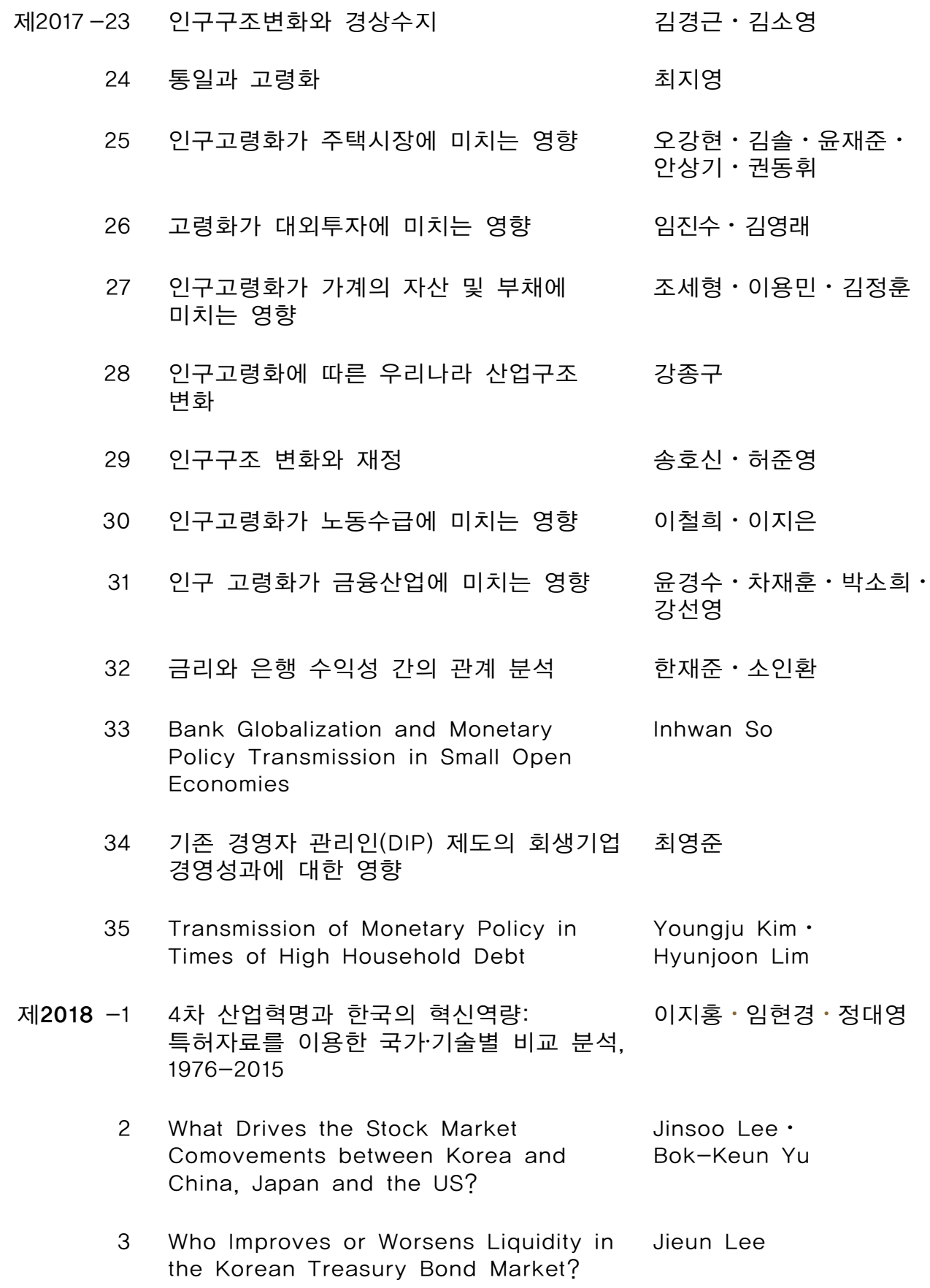

34 기존 경영자 관리인(DIP) 제도의 회생기업 경영성과에 대한 영향

35 Transmission of Monetary Policy in Times of High Household Debt

Youngju Kim • Hyunjoon Lim

제2018 -1 4차 산업혁명과 한국의 혁신역량:

특허자료를 이용한 국가-기술별 비교 분석, 1976-2015

2 What Drives the Stock Market Comovements between Korea and China, Japan and the US?

이지홍·임현경·정대영

3 Who Improves or Worsens Liquidity in Jieun Lee the Korean Treasury Bond Market?

Jinsoo Lee $\cdot$

Bok-Keun $\mathrm{Yu}$ 
제2018-4 Establishment Size and Wage Inequality: The Roles of Performance

Pay and Rent Sharing

5 가계대출 부도요인 및 금융업권별

금융취약성: 자영업 차주를 중심으로

6 직업훈련이 청년취업률 제고에 미치는 영향

7 재고투자와 경기변동에 대한 동학적 분석

8 Rare Disasters and Exchange Rates: An Empirical Investigation of Korean Exchange Rates under Tension between the Two Koreas

9 통화정책과 기업 설비투자 - 자산가격경로와 대차대조표경로 분석 -

10 Upgrading Product Quality: The Impact of Tariffs and Standards

11 북한이탈주민의 신용행태에 관한 연구

12 Uncertainty Shocks and Asymmetric Dynamics in Korea: A Nonlinear Approach

13 북한경제의 대외개방에 따른 경제적 후생 변화 분석

14 Central Bank Reputation and Inflation-Unemployment Performance: Empirical Evidence from an Executive Survey of 62 Countries

15 Reserve Accumulation and Bank Lending: Evidence from Korea

16 The Banks' Swansong: Banking and the Financial Markets under Asymmetric Information
Sang-yoon Song

정호성

최충·김남주 · 최광성

서병선·장근호

Cheolbeom Park •

Suyeon Park

박상준 · 육승환

Jihyun Eum

정승호·민병기·김주원

Kevin Larcher. Jaebeom Kim • Youngju Kim

정혁·최창용·최지영

In Do Hwang

Youngjin Yun

Jungu Yang 


\begin{tabular}{|c|c|c|}
\hline 제2018-17 & $\begin{array}{l}\text { E-money: Legal Restrictions Theory } \\
\text { and Monetary Policy }\end{array}$ & Ohik Kwon · Jaevin Park \\
\hline 18 & $\begin{array}{l}\text { 글로벌 금융위기 전·후 외국인의 채권투자 } \\
\text { 결정요인 변화 분석: 한국의 사례 }\end{array}$ & 유복근 \\
\hline 19 & $\begin{array}{l}\text { 설비자본재 기술진보가 근로유형별 임금 } \\
\text { 및 고용에 미치는 영향 }\end{array}$ & 김남주 \\
\hline 20 & $\begin{array}{l}\text { Fixed-Rate Loans and the } \\
\text { Effectiveness of Monetary Policy }\end{array}$ & Sung Ho Park \\
\hline 21 & $\begin{array}{l}\text { Leverage, Hand-to-Mouth Households, } \\
\text { and MPC Heterogeneity: Evidence from } \\
\text { Korea }\end{array}$ & Sang-yoon Song \\
\hline 22 & $\begin{array}{l}\text { 선진국 수입수요가 우리나라 수출에 } \\
\text { 미치는 영향 }\end{array}$ & 최문정·김경근 \\
\hline 23 & $\begin{array}{l}\text { Cross-Border Bank Flows through } \\
\text { Foreign Branches: Evidence from Korea }\end{array}$ & Youngjin Yun \\
\hline 24 & $\begin{array}{l}\text { Accounting for the Sources of the } \\
\text { Recent Decline in Korea's Exports to } \\
\text { China }\end{array}$ & $\begin{array}{l}\text { Moon Jung Choi } \\
\text { Kei-Mu Yi }\end{array}$ \\
\hline 25 & $\begin{array}{l}\text { The Effects of Export Diversification on } \\
\text { Macroeconomic Stabilization: Evidence } \\
\text { from Korea }\end{array}$ & $\begin{array}{l}\text { Jinsoo Lee } \\
\text { Bok-Keun Yu }\end{array}$ \\
\hline 26 & $\begin{array}{l}\text { Identifying Uncertainty Shocks due to } \\
\text { Geopolitical Swings in Korea }\end{array}$ & $\begin{array}{l}\text { Seohyun Lee } \cdot \text { Inhwan } \\
\text { So } \cdot \text { Jongrim } \mathrm{Ha}\end{array}$ \\
\hline 27 & $\begin{array}{l}\text { Monetary Policy and Income Inequality } \\
\text { in Korea }\end{array}$ & Jongwook Park \\
\hline 28 & $\begin{array}{l}\text { How the Financial Market Can Dampen } \\
\text { the Effects of Commodity Price Shocks }\end{array}$ & Myunghyun Kim \\
\hline 29 & $\begin{array}{l}\text { Which External Shock Matters in Small } \\
\text { Open Economies? US Economic Policy } \\
\text { Uncertainty vs. Global Risk Aversion }\end{array}$ & $\begin{array}{l}\text { Youngju Kim } \\
\text { Hyunjoon Lim }\end{array}$ \\
\hline 30 & $\begin{array}{l}\text { Do Korean Exports Have Different } \\
\text { Patterns over Different Regimes?: } \\
\text { New Evidence from STAR-VECM }\end{array}$ & $\begin{array}{l}\text { Sei-Wan Kim } \\
\text { Moon Jung Choi }\end{array}$ \\
\hline 31 & 기술진보와 청년고용 & 심명규·양희승·이서현 \\
\hline
\end{tabular}




\begin{tabular}{|c|c|c|}
\hline 제2018-32 & $\begin{array}{l}\text { 북한지역 장기주택수요 및 연관 } \\
\text { 주택건설투자 추정 }\end{array}$ & 이주영 \\
\hline 33 & 기업규모간 임금격차 원인 분석 & 송상윤 \\
\hline 34 & 우리나라 고용구조의 특징과 과제 & 장근호 \\
\hline 35 & 창업의 장기 고용효과: 시군구 자료 분석 & 조성철·김기호 \\
\hline 36 & 수출입과 기업의 노동수요 & 음지현·박진호·최문정 \\
\hline 37 & 청년실업의 이력현상 분석 & 김남주 \\
\hline 38 & $\begin{array}{l}\text { 노동시장 이중구조와 노동생산성: } \\
\mathrm{OECD} \text { 국가를 중심으로 }\end{array}$ & 최충·최광성·이지은 \\
\hline 39 & $\begin{array}{l}\text { 한국과 일본의 청년실업 비교분석 및 } \\
\text { 시사점 }\end{array}$ & 박상준·김남주·장근호 \\
\hline 40 & $\begin{array}{l}\text { 노동시장의 이중구조와 정책대응: } \\
\text { 해외사례 및 시사점 }\end{array}$ & 전병유·황인도·박광용 \\
\hline 41 & 최저임금이 고용구조에 미치는 영향 & 송헌재·임현준·신우리 \\
\hline 42 & $\begin{array}{l}\text { 최저임금과 생산성: } \\
\text { 우리나라 제조업의 사례 }\end{array}$ & 김규일·육승환 \\
\hline 43 & $\begin{array}{l}\text { Transmission of U.S. Monetary Policy } \\
\text { to Commodity Exporters and Importers }\end{array}$ & Myunghyun Kim \\
\hline 44 & $\begin{array}{l}\text { Determinants of Capital Flows in the } \\
\text { Korean Bond Market }\end{array}$ & Soohyon Kim \\
\hline 45 & $\begin{array}{l}\text { Central Bank Credibility and Monetary } \\
\text { Policy }\end{array}$ & Kwangyong Park \\
\hline 46 & $\begin{array}{l}\text { 통화정책이 자본유출입에 미치는 영향: } \\
\text { 행태방정식 분석 }\end{array}$ & 이명수·송승주 \\
\hline
\end{tabular}




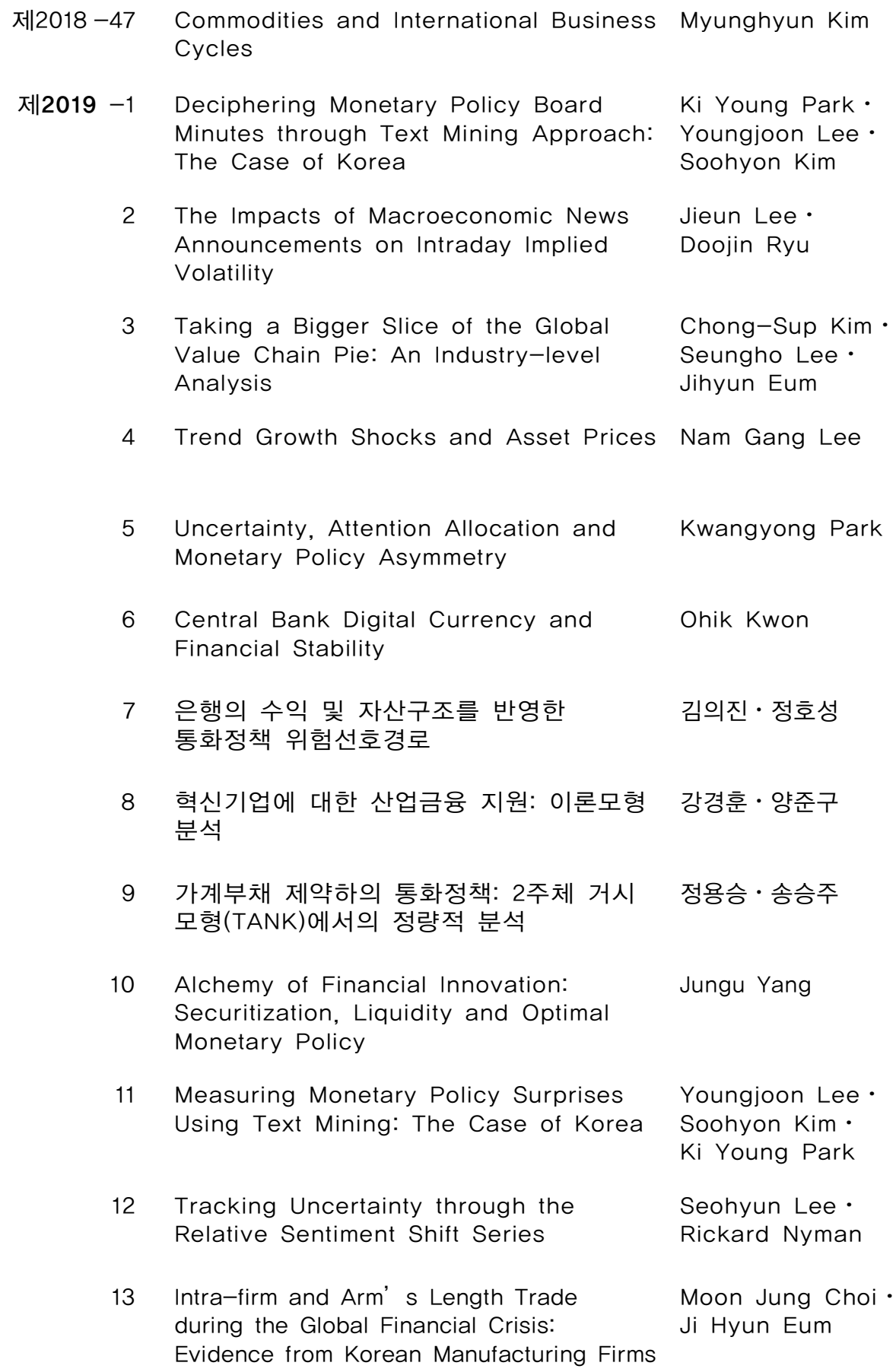

Youngjoon Lee

Soohyon Kim.

Ki Young Park

Seohyun Lee $\cdot$

Rickard Nyman

Moon Jung Choi Ji Hyun Eum 

제2019-14 특허자료를 이용한 우리나라 지식전파의 이지홍·남윤미
지역화 분석

15 Overhead Labour and Skill-Biased Technological Change: The Role of

Choong Hyun Nam

Product Diversification 

